\title{
ICPP Environmental Monitoring Report CY-1996
}

Engineering

Laboratory

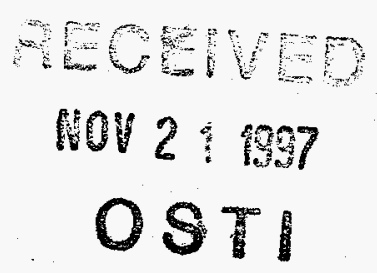

J. K. Neff 


\title{
ICPP Environmental Monitoring Report for CY-1996
}

\author{
J. K. Neff
}

Published June 1997

Idaho National Engineering and Environmental Laboratory

Environmental Support

Lockheed Martin Idaho Technologies Company

Idaho Falls, Idaho 83415

DSTRIEUTION OF THIS DOCUMENT IS UNHTHEO

Prepared for the

U.S. Department of Energy

Assistant Secretary for Environmental Management

Under DOE Idaho Operations Office

Contract DE-AC07-941D13223 


\section{DISCLAIMER}

Portions of this document may be illegible electronic image products. Images are produced from the best available original document. 


\section{TABLE OF CONTENTS}

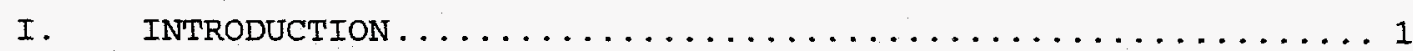

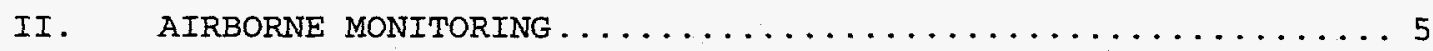

1. INTRODUCTION $\ldots \ldots \ldots \ldots \ldots \ldots \ldots \ldots \ldots \ldots \ldots \ldots \ldots \ldots \ldots \ldots \ldots \ldots \ldots$

2. AIRBORNE RELEASES TO THE ENVIRONMENT $\ldots \ldots \ldots \ldots \ldots \ldots$.

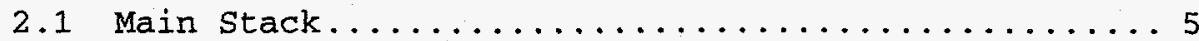

2.2 FAST Stack....................... 14

2.3 NWCF Stack.......................... 14

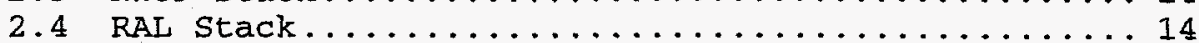

2.5 Coal Fired Steam Generating Facility (CFSGF) ..... 14

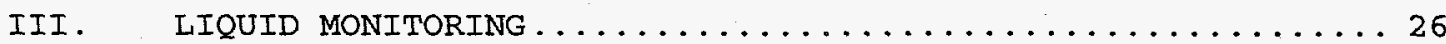

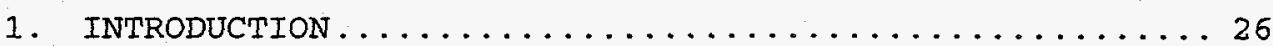

2. LIQUID RELEASES TO THE ENVIRONMENT $\ldots \ldots \ldots \ldots \ldots \ldots \ldots 26$

2.1 Service Waste System.................. 26

2.2 Sewage Treatment Plant................. 36

2.3 ICPP Injection Well .................. 36

\section{FIGURES}

$1-1$.

SUMMARY OF AIRBORNE RELEASES

$1-2$

$2-1$

$2-2$.

$2-3$.

$2-4$

$2-5$.

$2-6$

$2-7$.

$2-8$

$2-9$

$2-10$.

$2-11$

SUMMARY OF IIQUID RELEASES .

MAIN STACK EFFLUENT - Total Activity.............. 7

MAIN STACK EFFLUENT $-I-129 \ldots \ldots \ldots \ldots \ldots \ldots \ldots \ldots$

MAIN STACK EFFLUENT $-C S-137 \ldots \ldots \ldots \ldots \ldots \ldots \ldots \ldots$

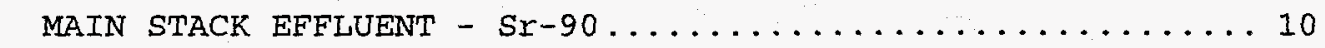

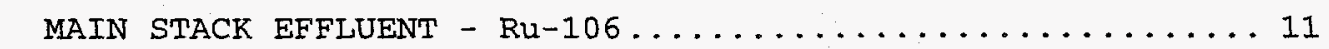

MAIN STACK EFFLUENT - Pu-Total .................. 12

MAIN STACK EFFLUENT $-S b-125 \ldots \ldots \ldots \ldots \ldots \ldots \ldots \ldots \ldots \ldots$

FAST STACK EFFLUENT - Total Activity $\ldots \ldots \ldots \ldots \ldots \ldots \ldots$

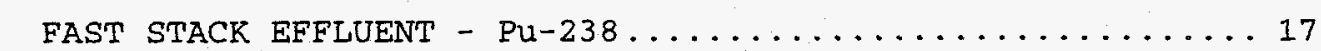

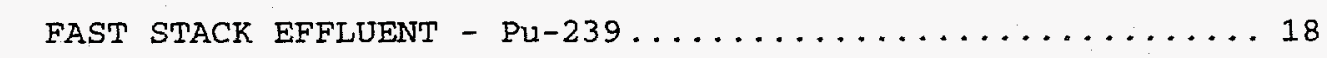

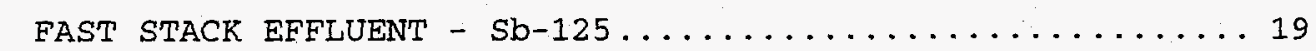




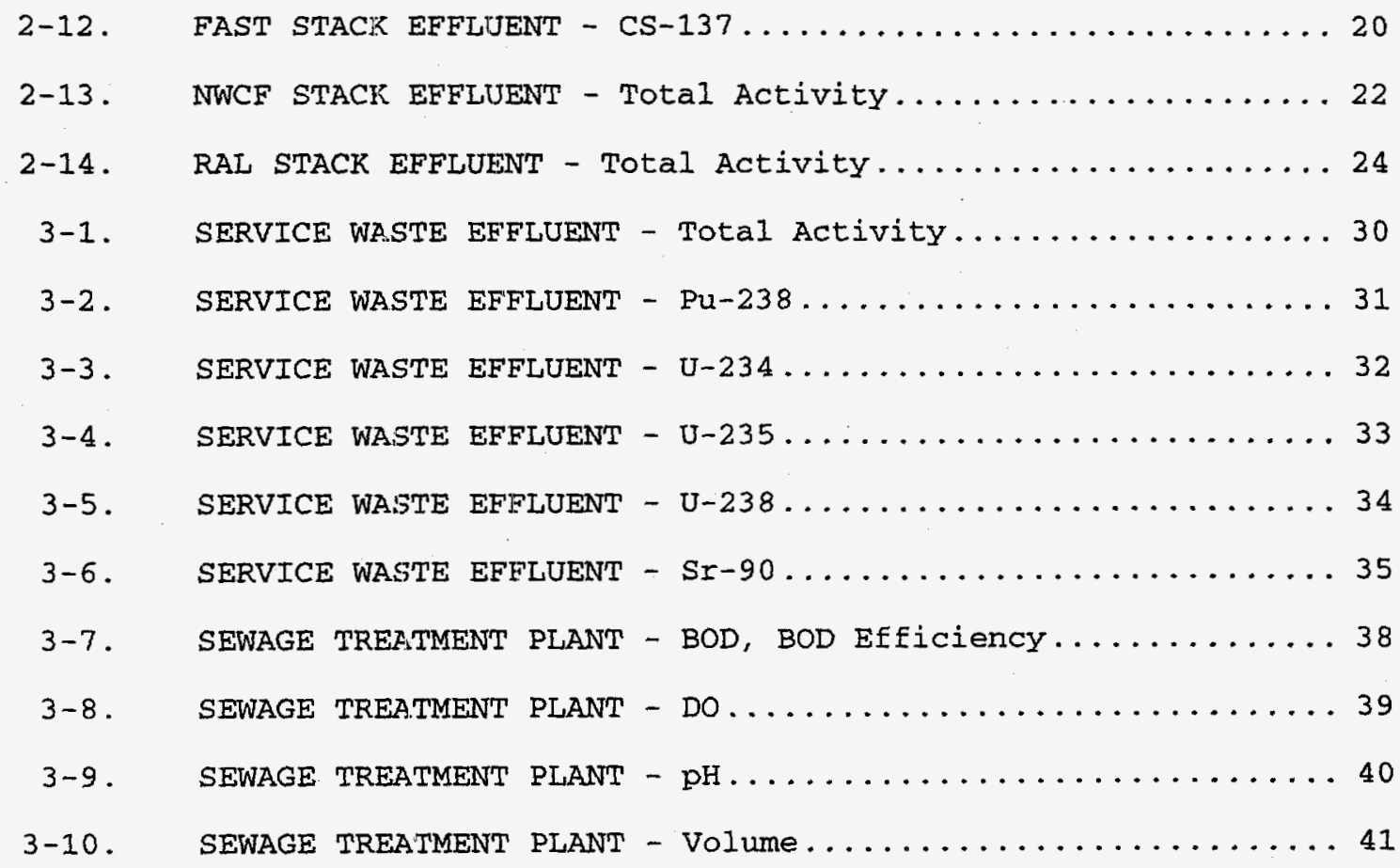

\section{TABLES}

1-1.

SUMMARY OF RELEASE DATA FOR $1996 \ldots \ldots \ldots \ldots \ldots \ldots \ldots \ldots \ldots$

2-1. AIRBORNE REIEASES FROM ICPP MAIN STACK - CY-1996........6

2-2. AIRBORNE RELEASES FROM ICPP FAST STACK - CY-1996....... 15

2-3. AIRBORNE RELEASES FROM ICPP NWCF STACK - CY-1996....... 21

2-4. AIRBORNE RELEASES FROM ICPP RAL STACK - CY-1996....... 23

2-5. COAL FIRED STEAM GENERATING FACILITY - CY-1996 ........ 25

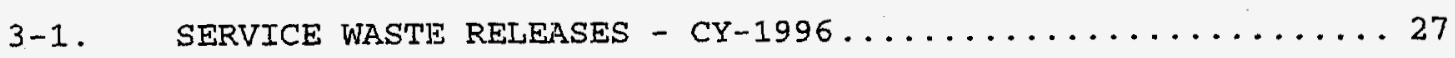

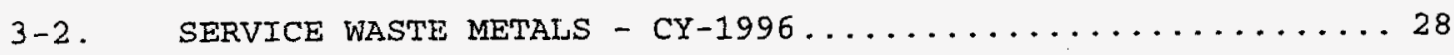

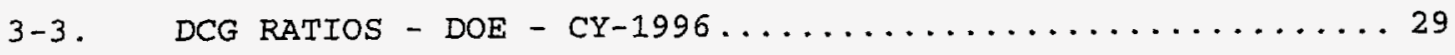

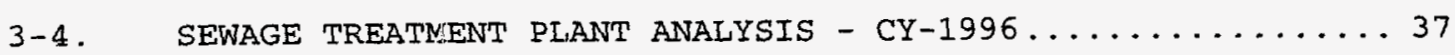




\section{ACRONYM LIST}

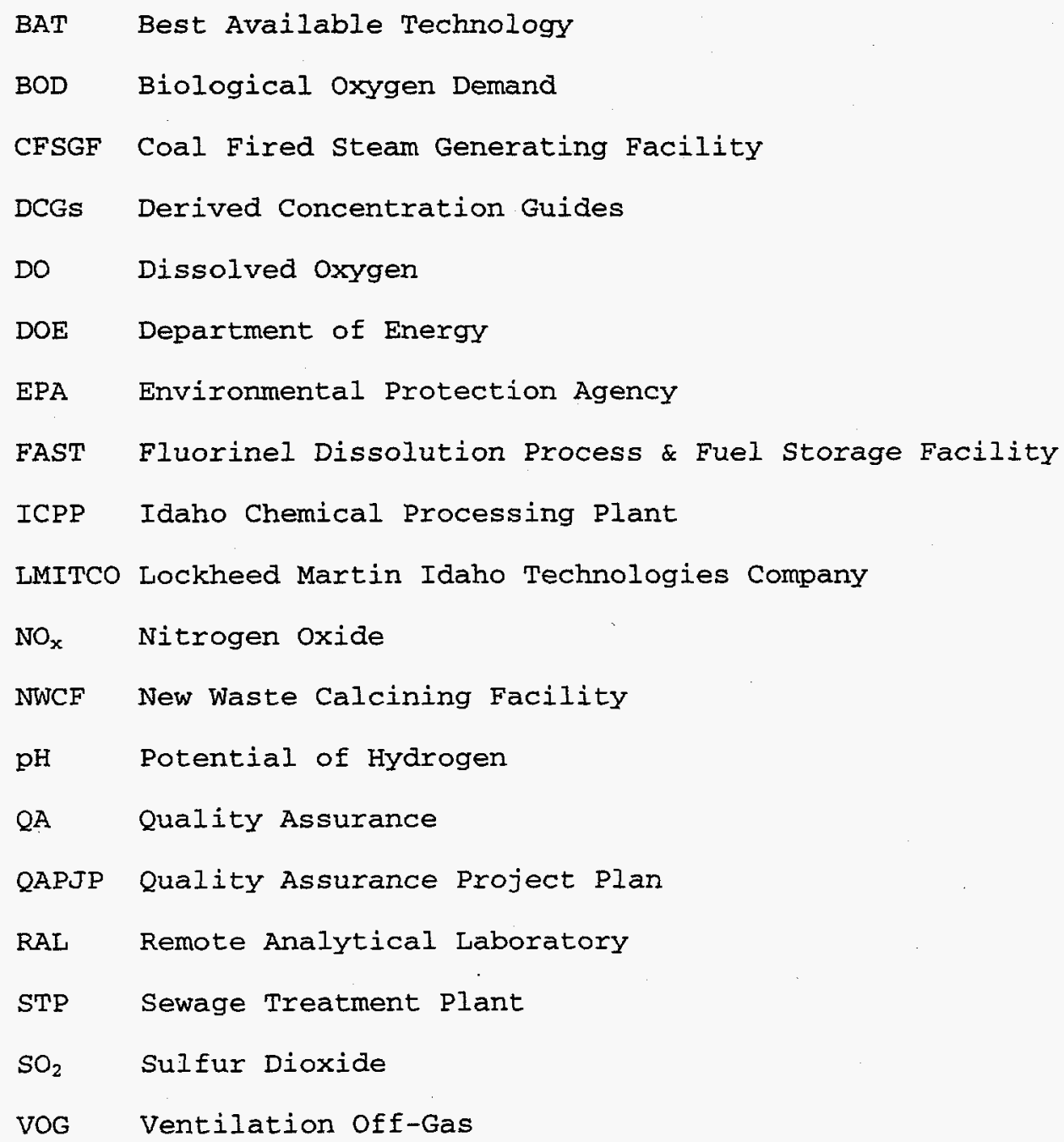




\section{ICPP ENVIRONMENTAL MONITORING REPORT 1996}

\section{INTRODUCTION}

Summarized in this report are the data collected through Environmental Monitoring programs conducted at the Idaho Chemical Processing Plant (ICPP) by the Environmental Affairs Department. This report is published in response to DOE Order 5400.1 .

The ICPP is responsible for complying with all applicable Federal, state, Local and DOE Rules, Regulations and Orders. Radiological effluent and emissions are regulated by the DOE in accordance with the Derived Concentration Guides (DCGs) as presented in DOE Order 5400.5. The state of Idaho regulates nonradiological waste resulting from the ICPP operations including airborne, liquid, and solid waste.

Quality Assurance activities have resulted in the ICPP's implementation of the Environmental Protection Agency (EPA) rules and guidelines pertaining to the collection, analyses, and reporting of environmentally related samples. Where no EPA methods for analyses existed for radionuclides, Lockheed Martin Idaho Technologies Company (LMITCO) methods were used.

Table 1-1 summarizes the volumes and activity released from ICPP stacks and liquid release points. Figure $1-1$ is a graphic representation of cumulative volume \& airborne releases and Figure $1-2$ depicts cumulative volume \& liquid releases for the year. The graphs allow trends to be made of waste volume and activity released for the year. The Main Stack gaseous monitor was not in operation until May 1996. New Waste Calcining Facility (NWCF) was not in operation in 1996. During 1996 the cumulative airborne and liquid release of radionuclides was $3.2 \mathrm{E}-2$ curies. Airborne releases to the atmosphere contributed $3.1 \mathrm{E}-02$ curies and liquid effluent released to the percolation Pond contributed 1.3E-03 curies. Liquid Effluent Treatment and Disposal (LET\&D) began operation on January 1, 1993. PEW condensates which previously were discharged to service waste are now treated in the LET\&D facility. Table 3-1 and 3-2 provide information on radionuclide activity and concentration of inorganic chemicals present in the service waste. 
Table 1-1

SUMMARY OF RELEASE DATA FOR 1996

$\begin{array}{cc}\text { Volume } & \text { AIREORNE } \\ (\mathrm{E}+09 \mathrm{~m} 3) & \begin{array}{l}\text { Activity } \\ \text { (curies) }\end{array}\end{array}$

\begin{tabular}{|c|c|c|c|c|}
\hline Jan & $\begin{array}{l}\text { Month } \\
0.220\end{array}$ & $\begin{array}{l}\underline{Y T D} \\
0.220\end{array}$ & $\begin{array}{l}\text { Month } \\
4.58 \mathrm{E}-06\end{array}$ & $\begin{array}{c}\mathrm{YTD} \\
4.58 \mathrm{E}-06\end{array}$ \\
\hline $\mathrm{Feb}$ & 0.260 & 0.480 & $1.52 \mathrm{E}-05$ & $1.98 \mathrm{E}-05$ \\
\hline Mar & 0.330 & 0.810 & $7.83 \mathrm{E}-06$ & $2.76 \mathrm{E}-05$ \\
\hline Apr. & 0.275 & 1.085 & $1.10 \mathrm{OE}-05$ & $3.86 \mathrm{E}-05$ \\
\hline May. & 0.254 & 1.339 & $2.41 \mathrm{E} 04$ & $2.80 \mathrm{E}-04$ \\
\hline Jun & 0.340 & 1.679 & $9.37 \mathrm{E}-05$ & 3.73E-04 \\
\hline Jul & 0.366 & 2.045 & $4.64 \mathrm{E}-03$ & $5.01 \mathrm{E}-03$ \\
\hline Aug & 0.236 & 2.281 & $8.01 \mathrm{E}-03$ & $1.30 \mathrm{O}-02$ \\
\hline Sep. & 0.339 & 2.620 & $4.92 \mathrm{E}-03$ & $\begin{array}{r}1.79 \mathrm{E}-02 \\
.1 .792\end{array}$ \\
\hline Oct. & 0.203 & 2.823 & $1.26 \mathrm{E}-02$ & $3.05 \mathrm{E}-02$ \\
\hline Nov & 0.187 & 3.010 & $4.34 \mathrm{E}-04$ & $3.10 \mathrm{E}-02$ \\
\hline Dec & 0.253 & 3.263 & $3.75 \mathrm{E}-05$ & $3.10 \mathrm{E}-02$ \\
\hline
\end{tabular}

LIQUID

Volume

(E+09 L)

Activity

(curies)

\begin{tabular}{|c|c|c|c|}
\hline $\begin{array}{l}\text { Month } \\
0.212\end{array}$ & $\begin{array}{l}\text { YTD } \\
0.212\end{array}$ & $\begin{array}{l}\text { Month } \\
7.12 \mathrm{E}-04\end{array}$ & $\begin{array}{c}\text { YTD } \\
7.12 \mathrm{E}-04\end{array}$ \\
\hline o.175 & 0.387 & & $7.12 \mathrm{E}-04$ \\
\hline 0.161 & 0.548 & $5.83 E-04$ & $1.30 \mathrm{~B}-03$ \\
\hline 0.202 & 0.750 & & $1.30 \mathrm{E}-03$ \\
\hline 0.151 & 0.901 & & $1.30 \mathrm{E}-03$ \\
\hline 0.176 & 1.077 & & $1.30 \mathrm{E}-03$ \\
\hline 0.188 & 1.265 & & $1.30 \mathrm{E}-03$ \\
\hline 0.186 & 1.451 & & $1.30 \mathrm{E}-03$ \\
\hline 0.172 & 1.623 & & $1.30 \mathrm{E}-03$ \\
\hline 0.205 & 1.828 & & $1.30 \mathrm{E}-03$ \\
\hline 0.190 & 2.018 & & 1.30E-03 \\
\hline 0.201 & 2.219 & & $1.30 \mathrm{E}-03$ \\
\hline
\end{tabular}




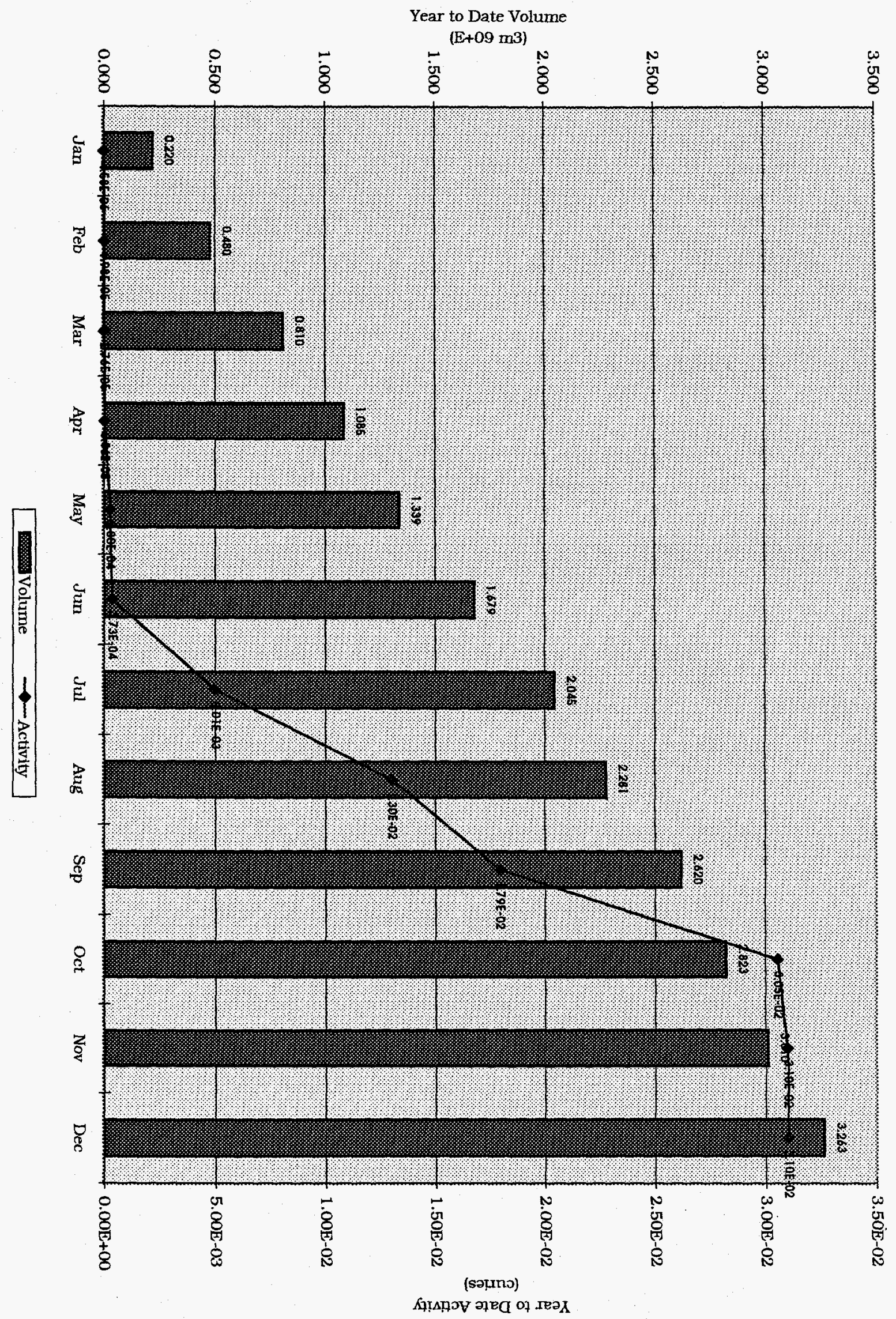

总 


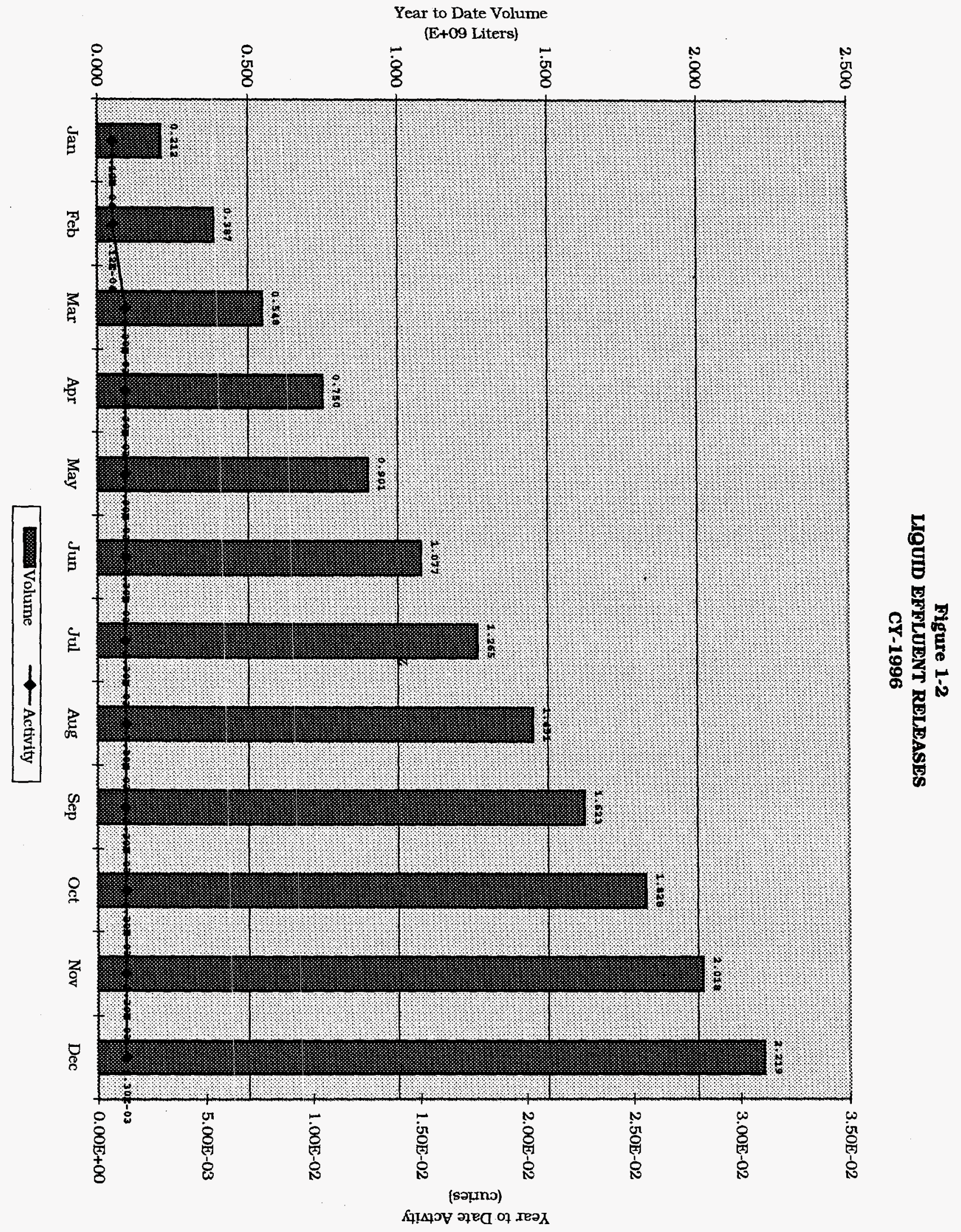




\section{AIRBORNE MONITORING}

\section{INTRODUCTION}

Airborne radioactive emissions are monitored from the Main Stack (CPP-708), the Fluorinel Dissolution Process and Fuel storage Facility (FAST) Stack (CPP767), the New Waste Calcining Facility (NWCF) Stack (CPP-659), and the Remote Analytical Laboratory (RAL) Stack (CPP-684). NWCF was not in operation in 1996. The Main Stack is equipped with radiological particulate and gaseous monitoring systems and the FAST stack is equipped with a particulate monitoring system. The Main stack gaseous monitor was not in operation until May 1996. The airborne monitoring systems are based upon a proportional isokinetic sample. Particulate filters are collected and analyzed daily on the Main stack. Nitrogen oxide $\left(\mathrm{NO}_{\mathbf{x}}\right)$ emissions are the only nonradioactive airborne contaminant that is monitored from the Main stack.

Particulate filters for the RAI stack are pulled and analyzed monthly and the FAST Stack filter is pulled and analyzed quarterly. The NWCF HVAC stack monitor filters were collected weekly through september 1996. Beginning in October 1996 the filters were collected monthly excluding December due to the previous month's filters reporting extremely low or below detection levels. The Ventilation Off-Gas (VOG) system is continuously monitored for radioactive particulates. The CFSGF is monitored for $\mathrm{NO}_{x}, \mathrm{SO}_{2}$, carbon monoxide (carbon monoxide emissions are monitored using coal feed rate and EPA AP-42 emission factors), and opacity in accordance with the state of Idaho, the EPA and the DOE-ID.

Radioactive releases for each emission point were well below the DOE DCGs for 1996. DCGs at the INEL boundary are reference values for conducting radiological environmental protection programs at operational DOE facilities and sites. Final data reduction is performed by the Environmental Support section of the Environmental Affairs Department.

\section{AIRBORNE RELEASES TO THE ENVIRONMENT}

\subsection{Main Stack}

Airborne radioactive release data from the Main Stack for each month and the year are given in Table 2-1. This information is presented graphically in Figure 2-1. Graphic presentations showing yearly trends for radionuclides most likely to be present (iodine-129, cesium-137, strontium90, ruthenium-106, plutonium (total), and antimony-125), are given in Figures 2-2 through 2-7, respectively.

Nitrogen oxide $\left(\mathrm{NO}_{\mathrm{x}}\right)$ emission from the Main stack is the only nonradioactive airborne contaminant continuously monitored. $\mathrm{NO}_{\mathbf{x}}$ concentration levels, while they do not violate any ambient air quality standard, must not exceed limits imposed by the FPR PSD permit. The limits set for the Main stack are 472 pounds per hour and 1700 tons per year. The total NOx released in 1996 was 0 tons. 


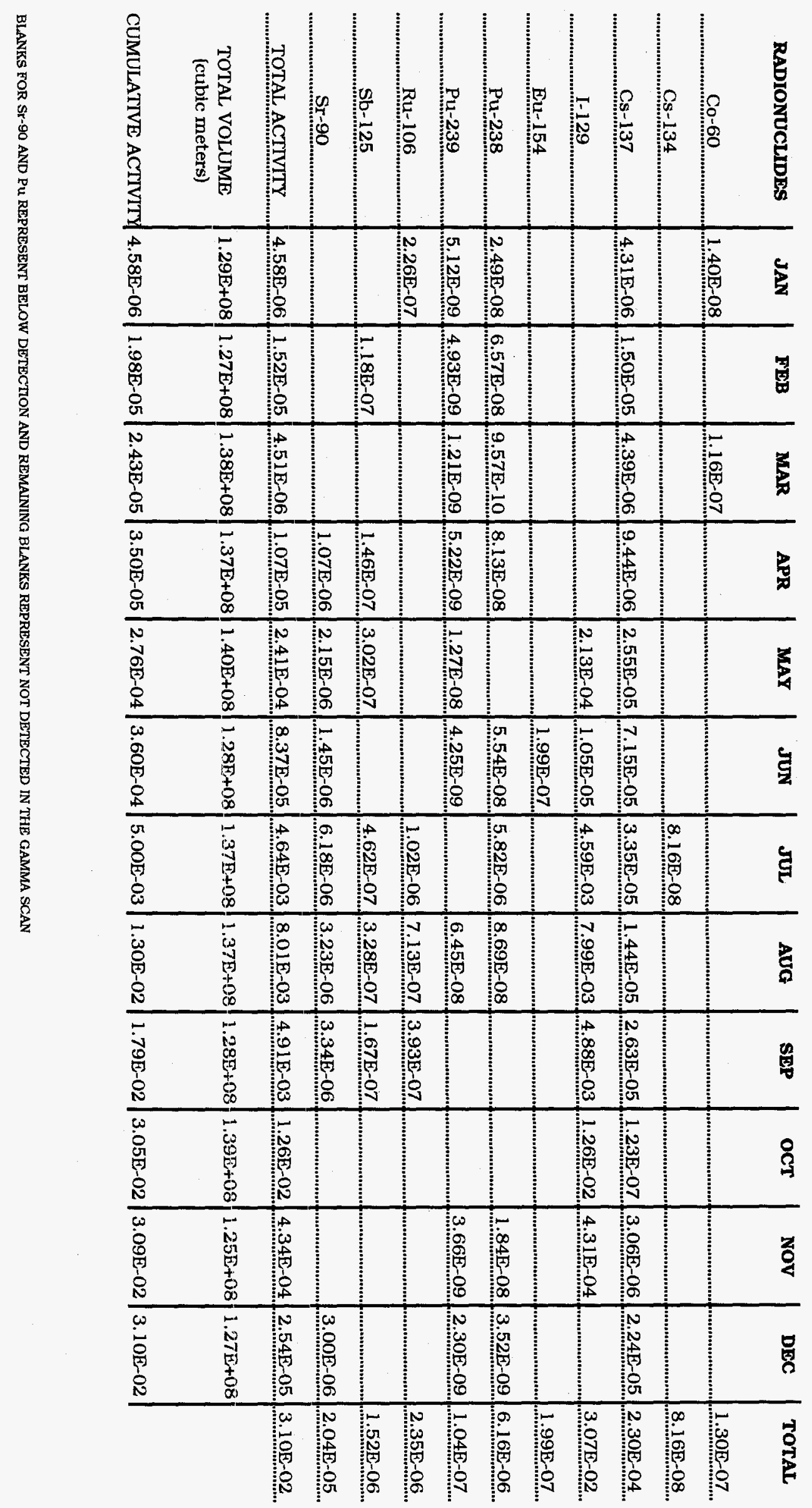

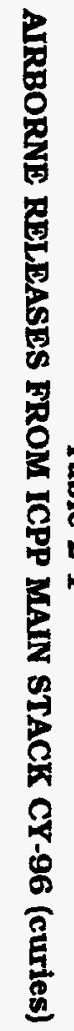




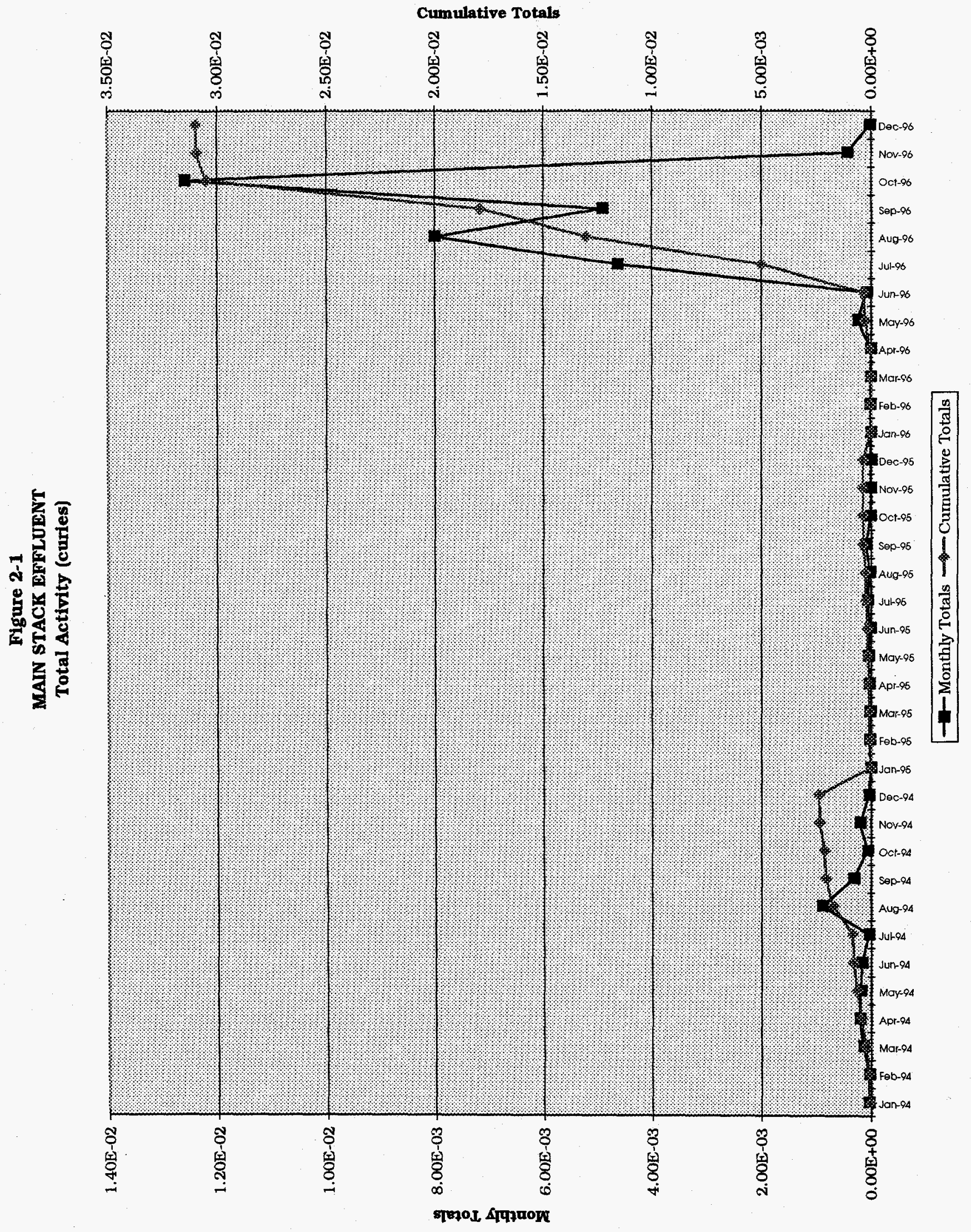




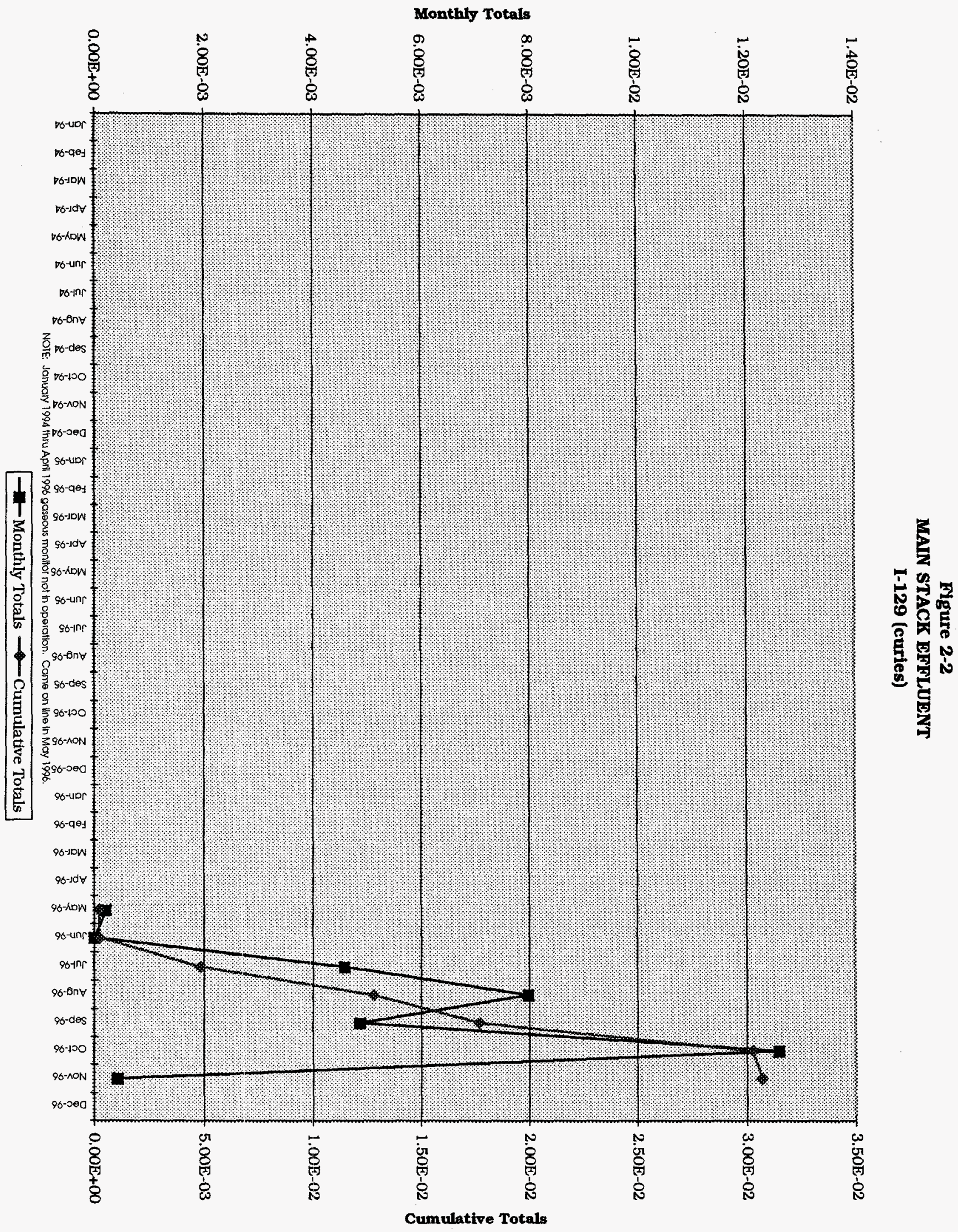




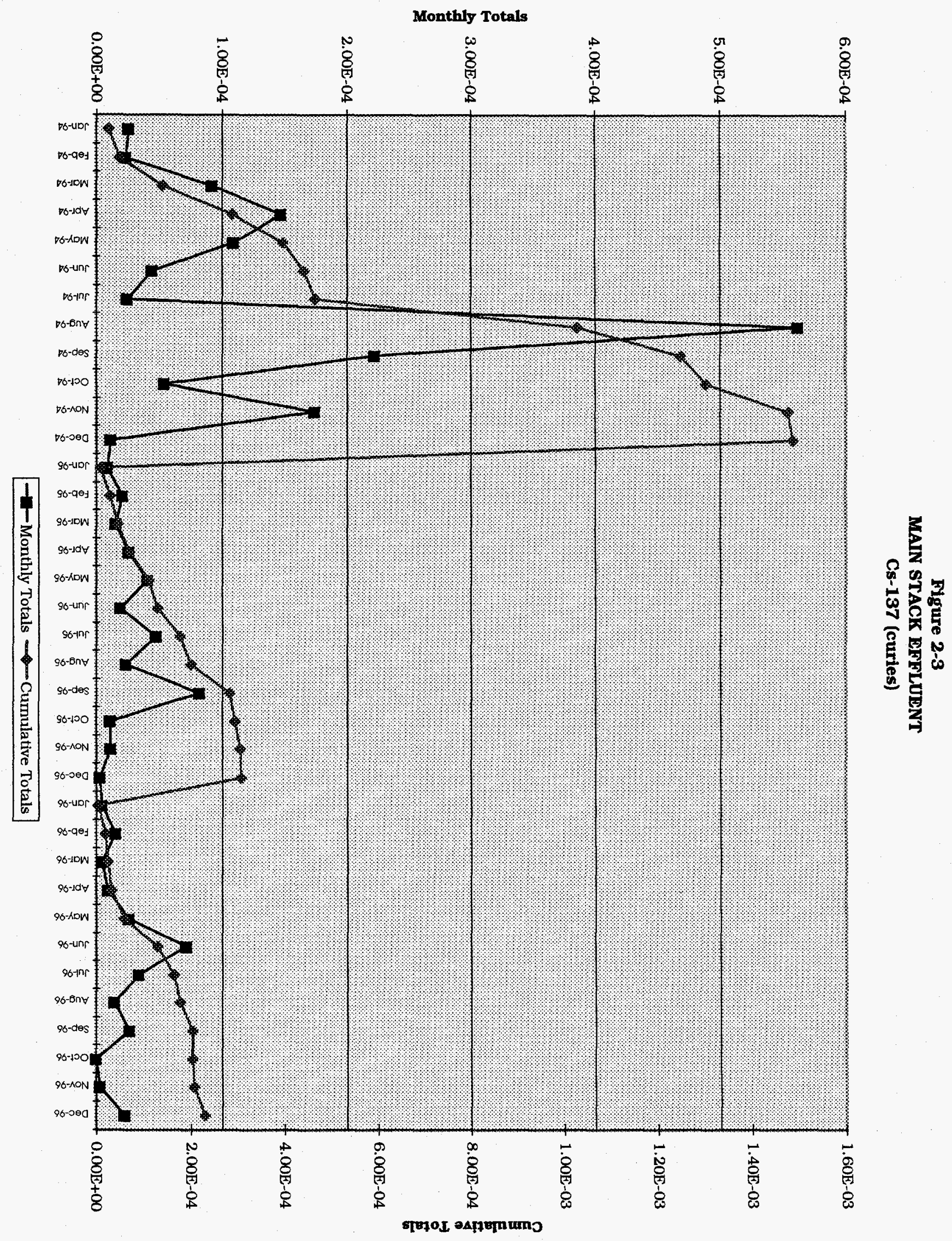




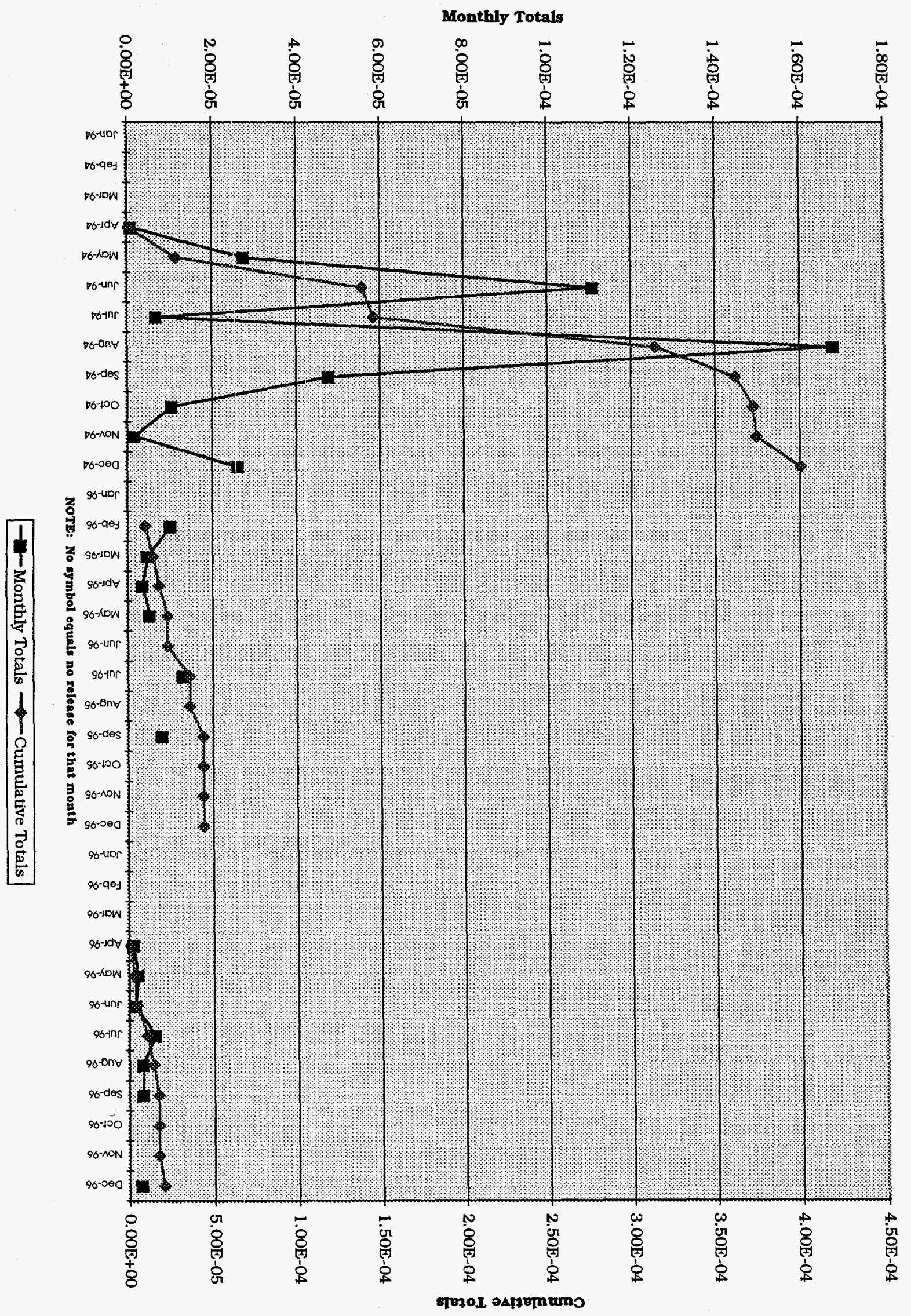

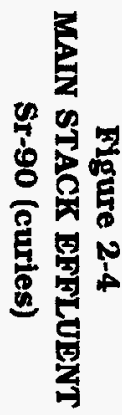




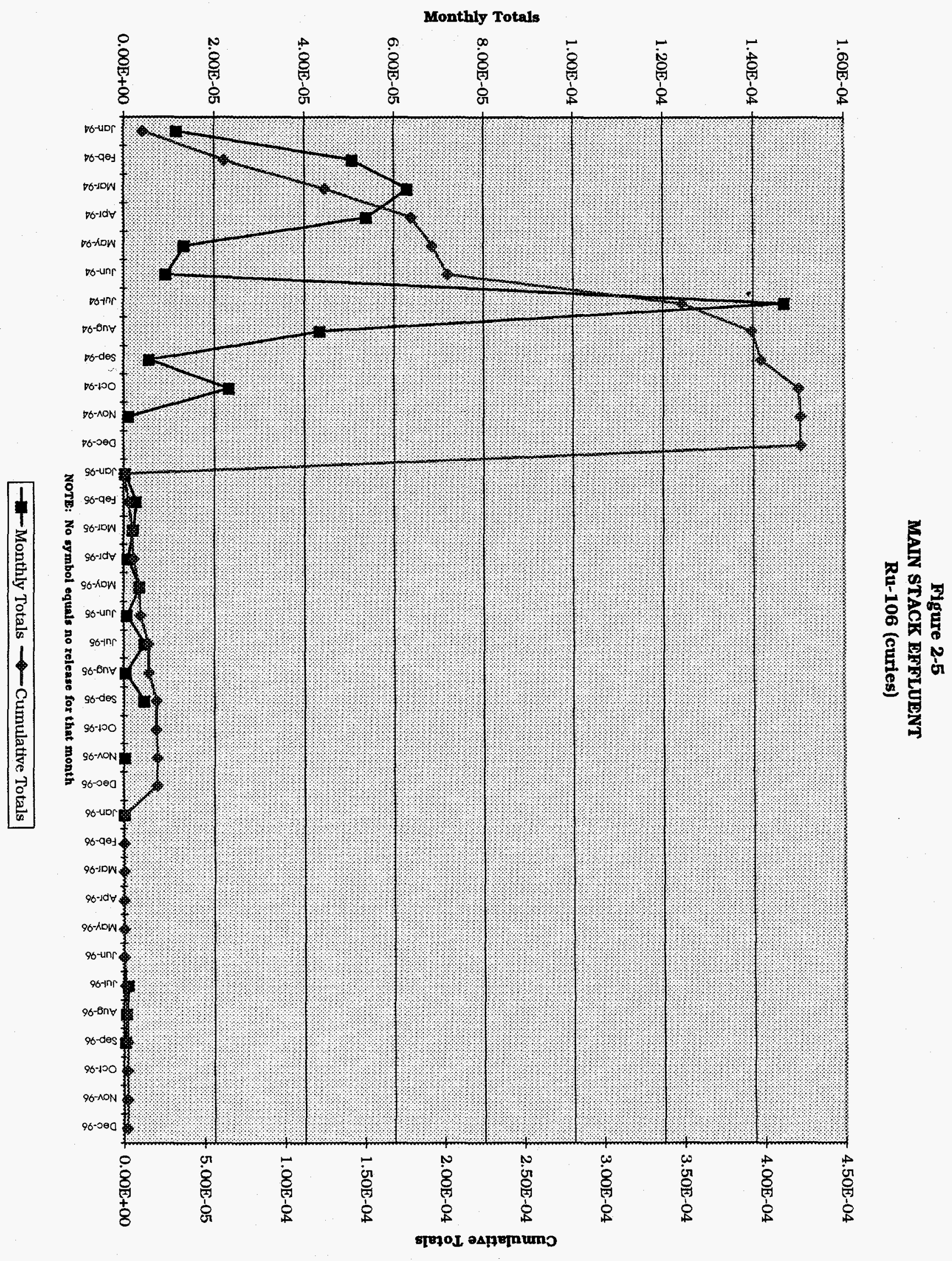




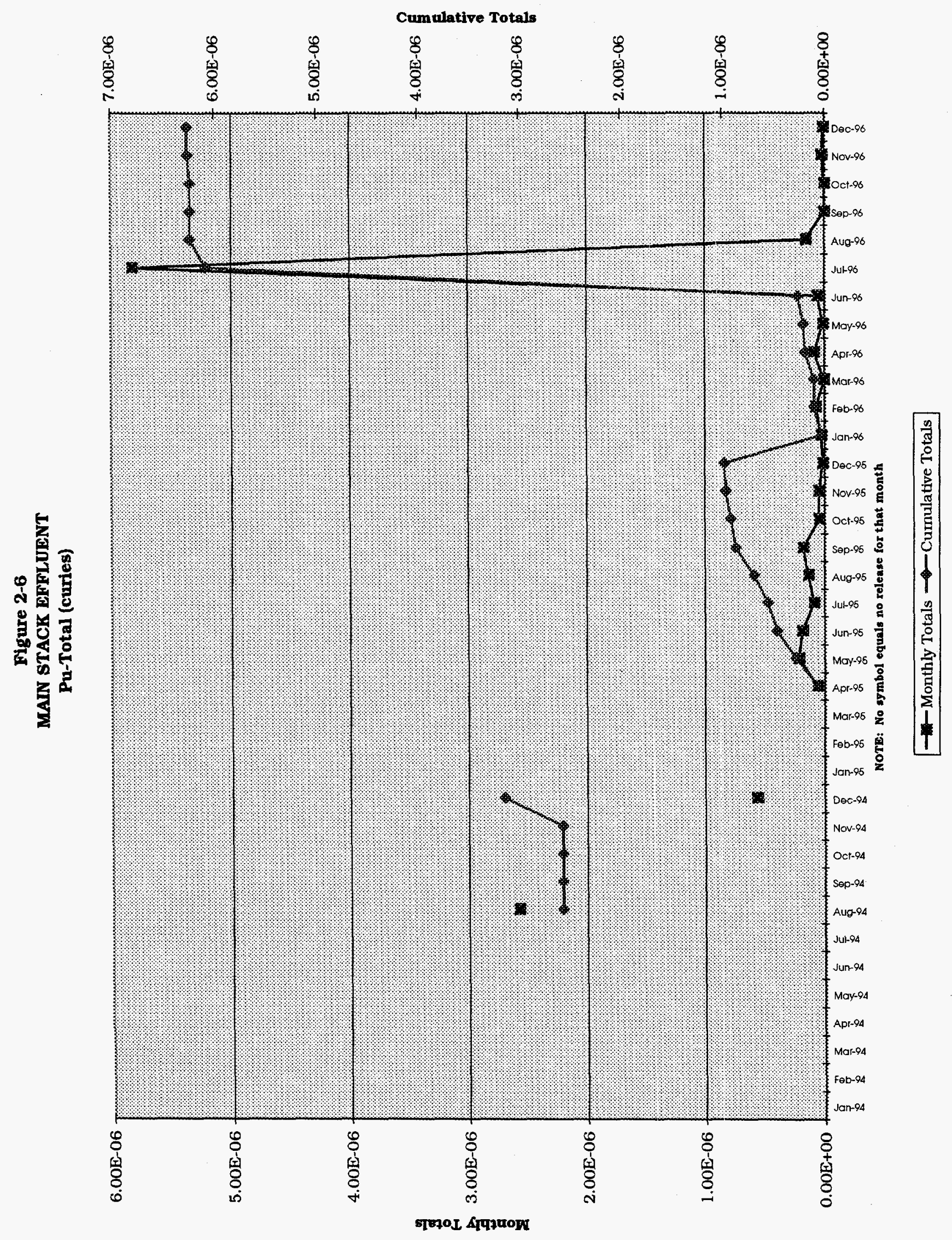


Figure 2-7

MAIN STACK EFFLUENT

Sb-125 (curies)

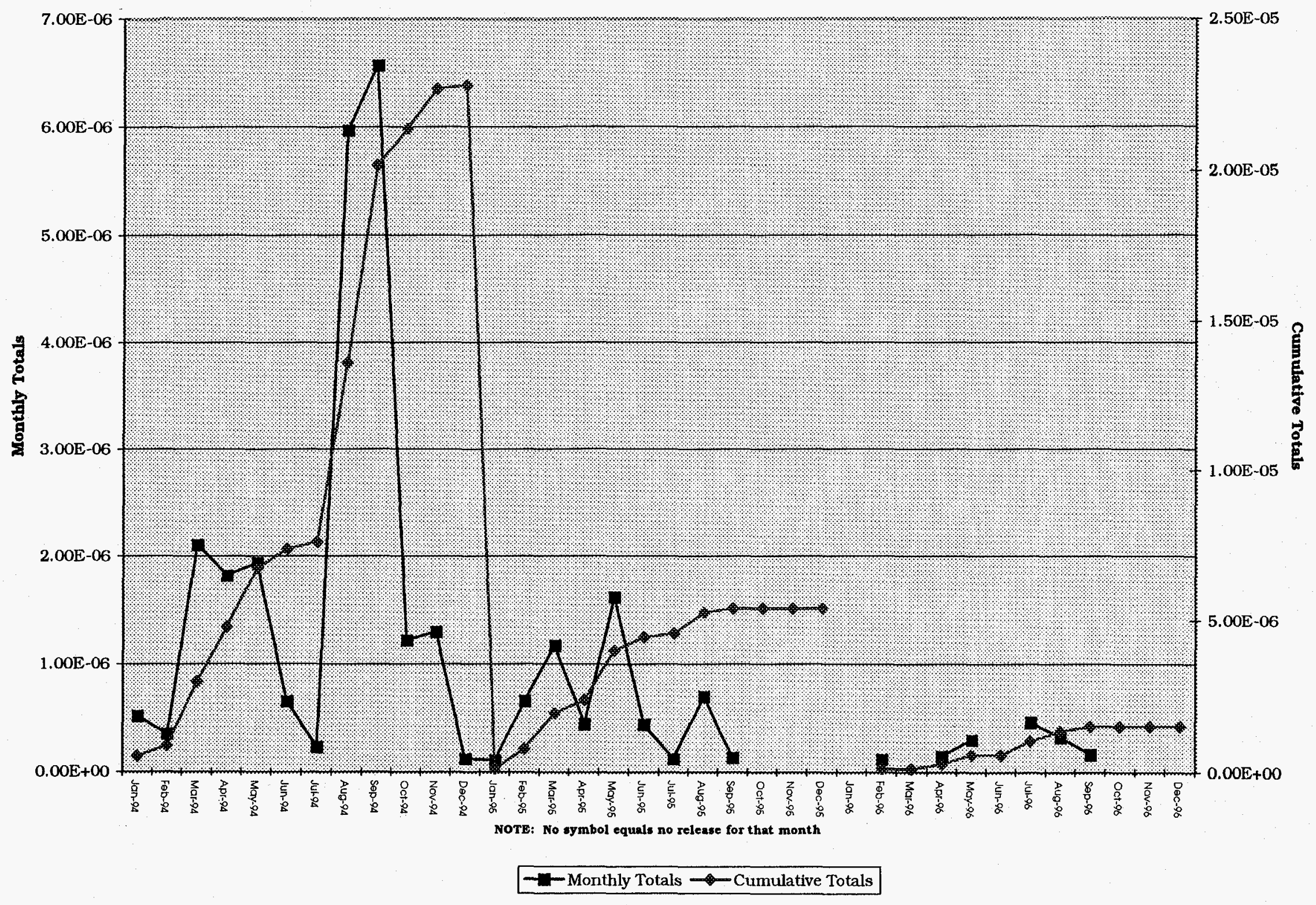


Table 2-2 lists the total radionuclide releases in curies from the FAST Stack per month by radionuclide and Figure 2-8 depicts the total activity. Graphic presentations for plutonium 238, plutonium 239, antimony-125, and cesium 137 showing yearly trends are given in Figures 2-9 through 2-12, respectively.

\subsection{NWCF Stack}

Table 2-3 presents the radioactive emissions from the NWCF VOG system. The radionuclides reported are those that have been routinely analyzed for in the ventilation stack emissions. Figure 2-13 depicts the total monthly activity.

\section{$2.4 \quad$ RAL Stack}

Table 2-4 presents the radioactive emissions from the RAL VOG system. The radionuclides reported are those that have been identified in the ventilation stack emissions. Figure 2-14 depicts the total monthly activity.

\subsection{Coal Fired Steam Generating Facility (CFSGF)}

The CFSGF stack is monitored continuously for sulfur dioxide $\left(\mathrm{SO}_{2}\right)$, nitrogen oxide $\left(\mathrm{NO}_{\mathrm{x}}\right)$, and opacity. Carbon monoxide $(\mathrm{CO})$ is calculated by using AP-42 emission factors and fuel consumption rates. Emission limits for the stack are set by the Environmental Protection Agency (EPA) and the State of Idaho. Table 2-5 lists the releases per month for the CFSGF. The facility must provide a minimum removal efficiency of $70 \%$ for $\mathrm{SO}_{2}$ calculated as an average over a 30 day period. $\mathrm{SO}_{2}$ emissions shall not exceed an average of 0.6 pounds per MM/Btu of fuel input averaged over a 24 hour period. $\mathrm{NO}_{\mathrm{x}}$ emissions shall not exceed an average of 0.5 pounds per MM/Btu of fuel input averaged over a 24 hour period when the steam load is

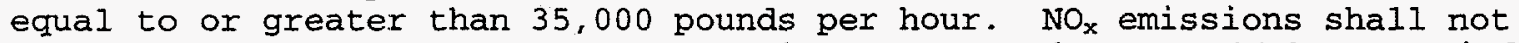
exceed 0.7 pounds per MM/Btu of fuel input averaged over a 24 hour period when the steam load is less than 35,000 pounds per hour. Carbon monoxide shall not exceed $148.5 \mathrm{lbs} / \mathrm{hr}$ or $650.4 \mathrm{tons} / \mathrm{yr}$. Opacity limit for the CFSGF is $20 \%$. 
Table 2-2

AIRBORNE RELEASES FROM ICPP FAST STACK FY-1996

(curies)

\begin{tabular}{|c|c|c|c|c|c|c|c|c|c|c|c|c|c|}
\hline RADIONUCLIDES & JAN & FEB & MAR & APR & MAY & JUN & JUL & AUG & SEP & OCT & NOV & DEC & TOTAL \\
\hline $\mathrm{Co}-60$ & & & & & & & & & & & & & \\
\hline Cs-134 & & & & & & $5.08 \mathrm{E}-07$ & & & & & & & \\
\hline Cs-137 & & & $3.19 \mathrm{E}-08$ & & & & & & & & & & $3.19 \mathrm{E}-08$ \\
\hline Eu-152 & & & & & & & & & & & & & \\
\hline Eu-154 & & & & & & & & & & & & & \\
\hline $\mathrm{Pu}-238$ & & & $1.83 \mathrm{E}-09$ & & & 8.50E-10 & 1.03E-07 & & 5.47E-09 & & & & $1.11 \mathrm{E}-07$ \\
\hline $\mathrm{Pu}-239$ & & & $1.66 \mathrm{E}-09$ & & & $7.24 \mathrm{E}-10$ & & & 5.04E-09 & & & & 7.42E-09 \\
\hline $\mathrm{Ru}-106$ & & & & & & & & & & & & & \\
\hline Sb-125 & & & $3.28 \mathrm{E}-06$ & & & $9.42 \mathrm{E}-06$ & $1.36 \mathrm{E}-06$ & & $8.18 \mathrm{E}-06$ & & & $1.21 \mathrm{E}-05$ & 3.43E-05 \\
\hline Sr-90 & & & & & & & & & & & & & $0.00 E+00$ \\
\hline TOTAL ACTIVITY & & & $3.32 \mathrm{E}-06$ & & & $9.93 \mathrm{E}-06$ & $1.46 \mathrm{E}-06$ & & 8.19E-06 & & & $1.21 \mathrm{E}-05$ & $3.50 \mathrm{E}-05$ \\
\hline $\begin{array}{l}\text { TOTAL VOLUME } \\
\text { (cubic meters) }\end{array}$ & & & $1.05 \mathrm{E}+08$ & & & $1.05 \mathrm{E}+08$ & $1.05 E+08$ & & $1.05 \mathrm{E}+08$ & & & $1.05 \mathrm{E}+08$ & \\
\hline CUMULATIVE ACTIVITY & & & $3.32 \mathrm{E}-06$ & $3.32 \mathrm{E}-06$ & 3.32E-06 & $1.32 \mathrm{E}-05$ & $1.47 \mathrm{E}-05$ & $1.47 \mathrm{E}-05$ & $2.29 \mathrm{E}-05$ & $2.29 \mathrm{E}-05$ & $2.29 \mathrm{E}-05$ & $3.50 \mathrm{E}-05$ & \\
\hline
\end{tabular}


Figure 2-8

FAST STACK EFFLUENT

Total Activity (curies)

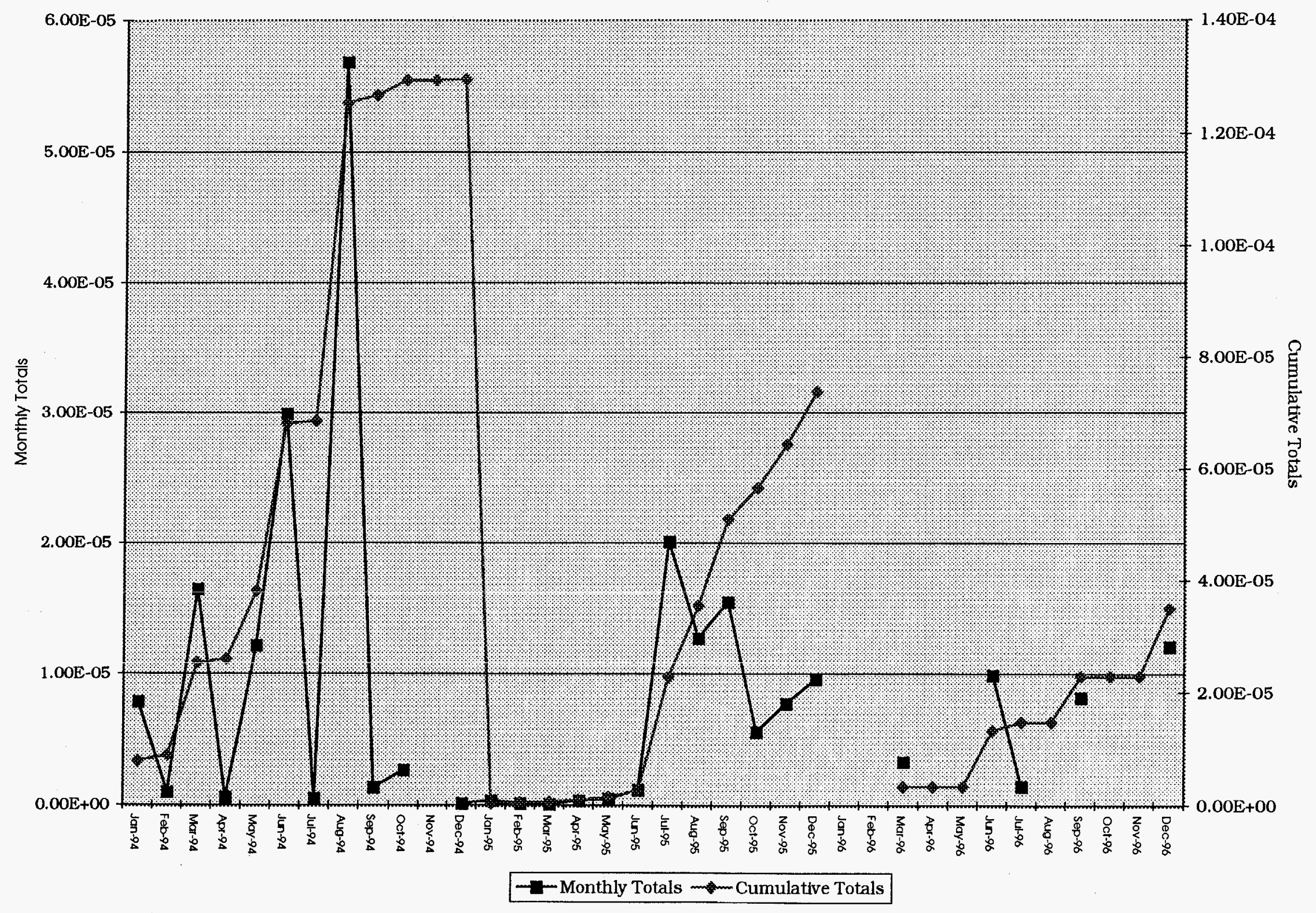




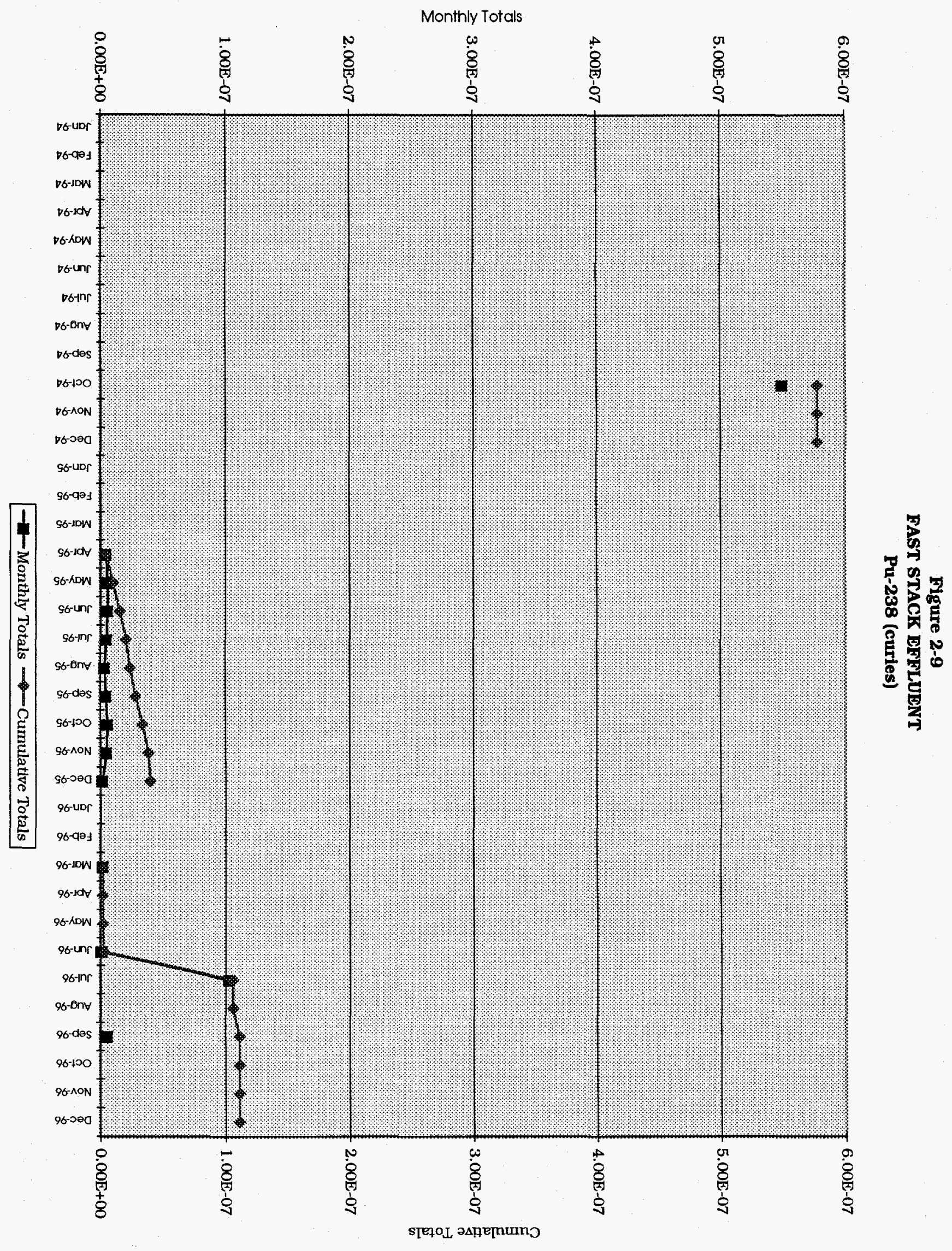




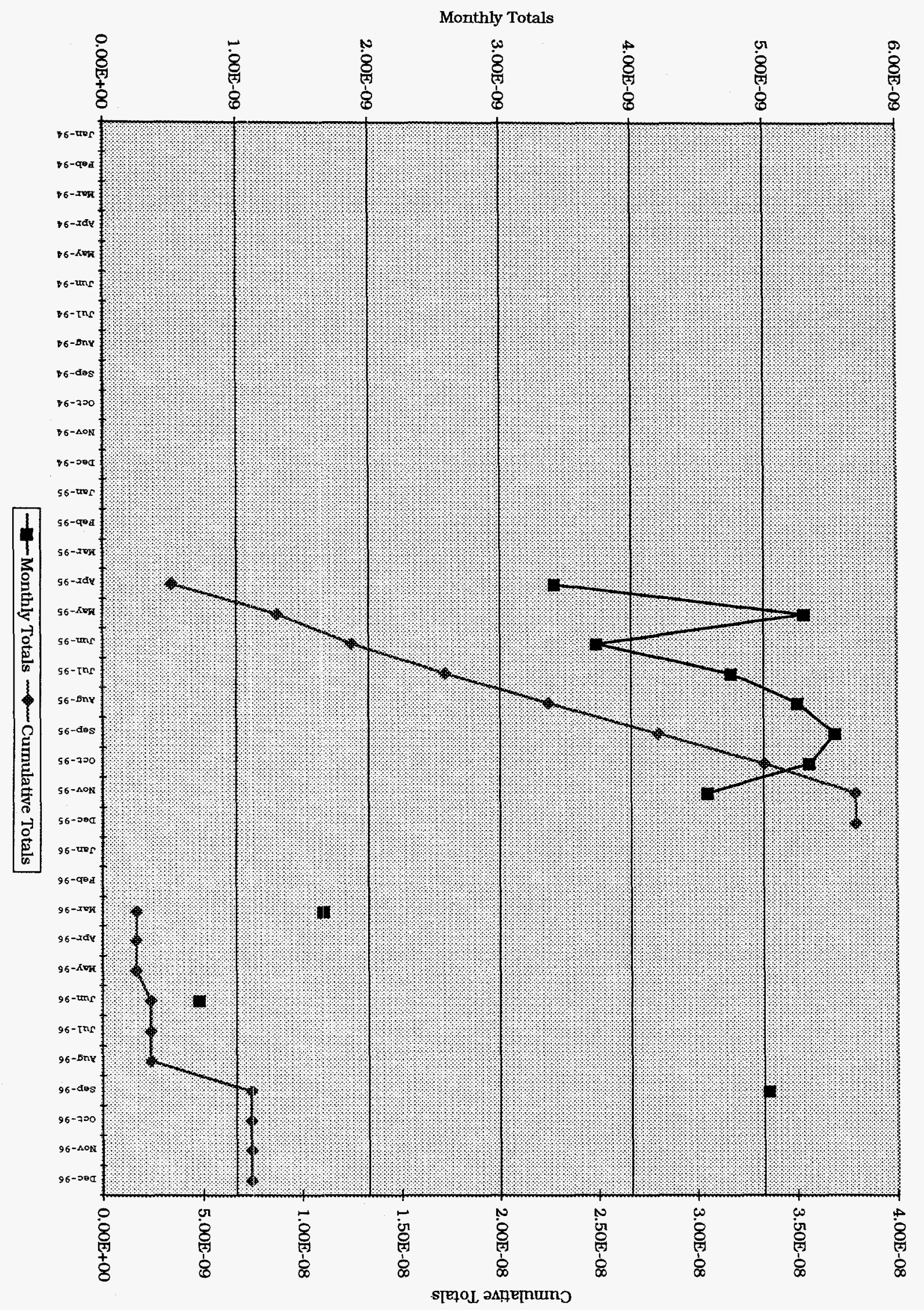

是 


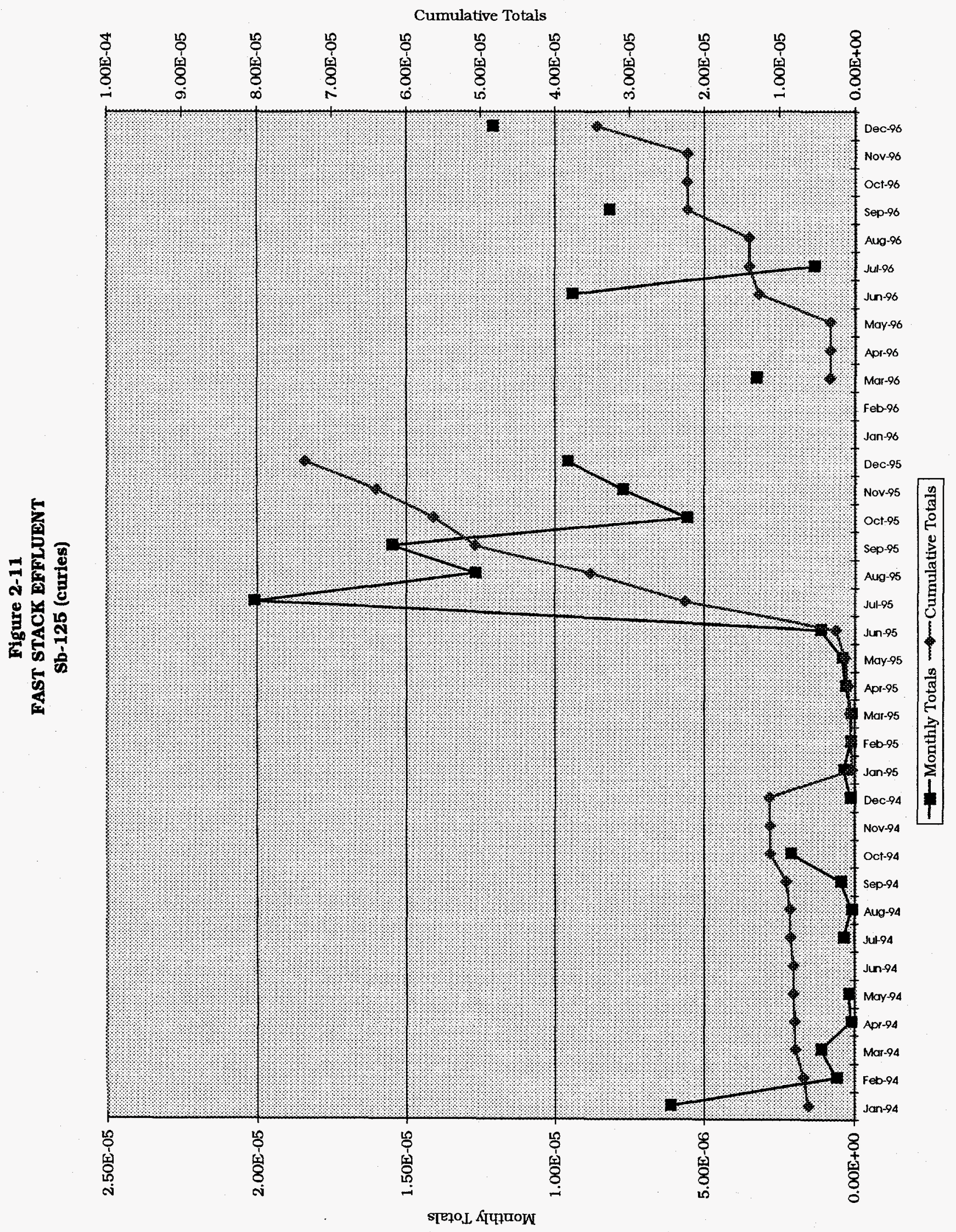




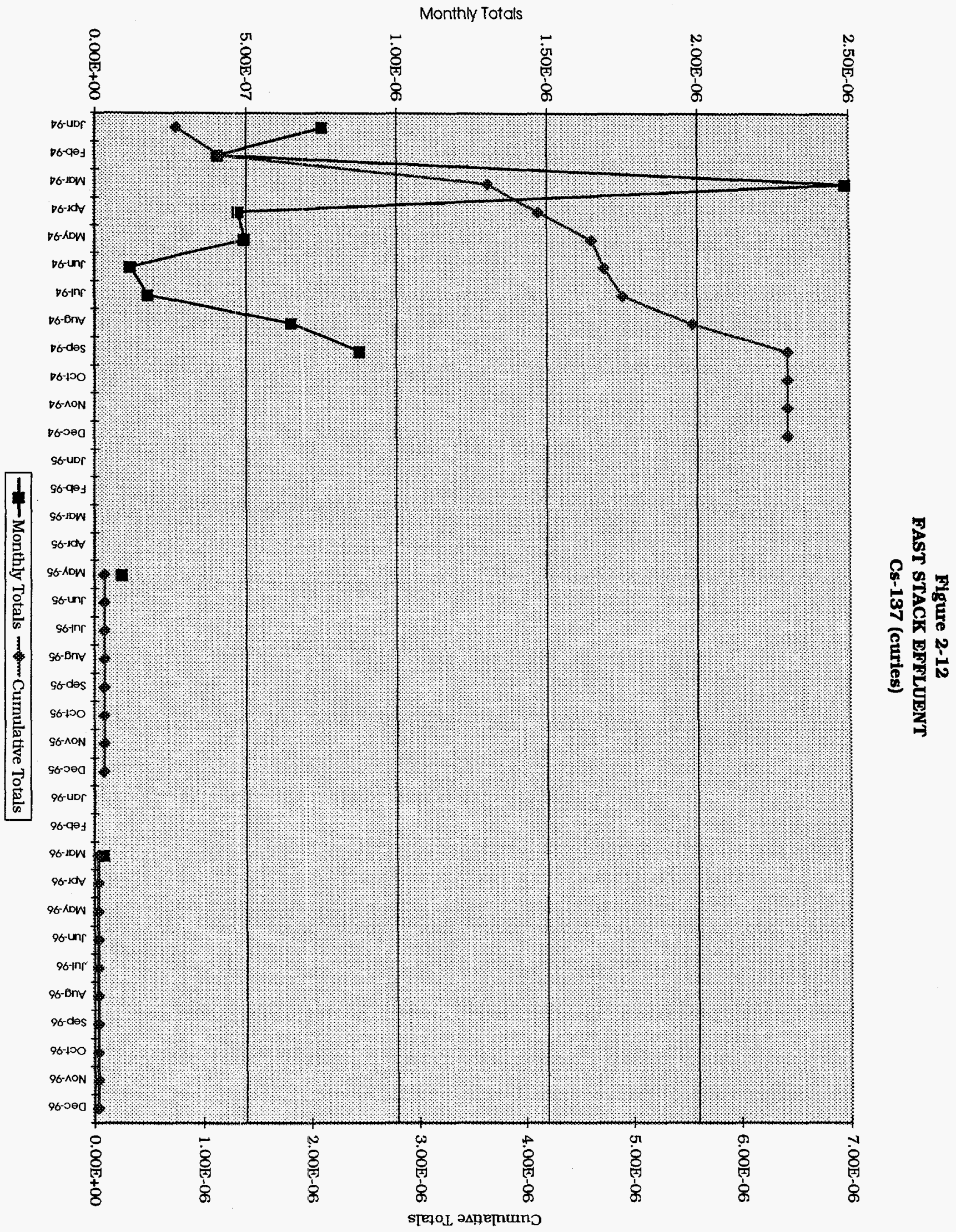


Table 2-3

AIRBORNE RELEASES FROM ICPP NWCF CY-1996

(curies)

AIRBORNE RELEASES FROM ICPP NWCF STACK CY-1996

(curies)

\begin{tabular}{|c|c|c|c|c|c|c|c|c|c|c|c|c|c|}
\hline $\begin{array}{l}\text { RADIONUCLIDES } \\
\text { CS-137 }\end{array}$ & JAN & FEB & MAR & APR & MAY & JUN & JUL & AUG & SEP & $\begin{array}{c}\text { OCT } \\
2.00 \mathrm{E}-08 \\
\end{array}$ & 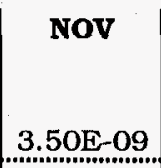 & DEC & $\begin{array}{l}\text { TOTAL } \\
2.35 \mathrm{E}-08\end{array}$ \\
\hline Co-60 & & & & & & $7.95 \mathrm{E}-08$ & & & & & & & $7.95 \mathrm{E}-08$ \\
\hline Pu-238 & & & & & & & & & & $4.61 \mathrm{E}-12$ & $7.50 \mathrm{E}-11$ & & $7.96 \mathrm{E}-11$ \\
\hline Pu-239 & & & & & & & & & & $2.75 \mathrm{E}-11$ & $1.72 \mathrm{E}-11$ & & 4.47E-11 \\
\hline Ru-106 & & & & & & & & & & 1 1.00E-08 & $-2.50 \mathrm{E}-07$ & & $-2.40 \mathrm{E}-07$ \\
\hline $\mathrm{Sb}-125$ & & & & & & & & & & $-1.50 \mathrm{E}-08$ & & & $-1.50 \mathrm{E}-08$ \\
\hline $\mathrm{Sr}-90$ & & & & $2.74 \mathrm{E}-07$ & & & & & & 2.00E-09 & $-3.50 \mathrm{E}-09$ & & $2.73 \mathrm{E}-07$ \\
\hline TOTAL ACTIVITY & & & & $2.74 \mathrm{E}-07$ & & $7.95 \mathrm{E}-08$ & & & & 1.70E-08 & $-2.50 \mathrm{E}-07$ & & $1.21 \mathrm{E}-07$ \\
\hline $\begin{array}{l}\text { TOTAL VOLUME } \\
\text { (cubic meters) }\end{array}$ & $7.03 E+07$ & $1.13 \mathrm{E}+08$ & $6.88 \mathrm{E}+07$ & $1.18 \mathrm{E}+08$ & $9.34 \mathrm{E}+07$ & $8.68 \mathrm{E}+07$ & $1.03 E+08$ & $7.77 \mathrm{E}+07$ & $8.57 \mathrm{E}+07$ & $4.33 \mathrm{E}+07$ & $4.14 \mathrm{E}+07$ & & \\
\hline CUMULATIVE ACTIVITY| & & & & $2.74 \mathrm{E}-07$ & $2.74 \mathrm{E}-07$ & $3.54 \mathrm{E}-07$ & $3.54 \mathrm{E}-07$ & $3.54 \mathrm{E}-07$ & $3.54 \mathrm{E}-07$ & $3.71 \mathrm{E}-07$ & $1.21 \mathrm{E}-07$ & $1.21 \mathrm{E}-07$ & \\
\hline
\end{tabular}

BEGINNING IN OCTOBER CALCULATIONS SHEEIS WERE REVISED, NOW USING ALL VALUES INCLUDING NON-DETECTABLES.

BLANKS REPRESENI BELOW DETECTION UMITS

No filtex pulled in December 
Figure 2-13

NWCF STACK EFFLUENT

Total Activity (curies)

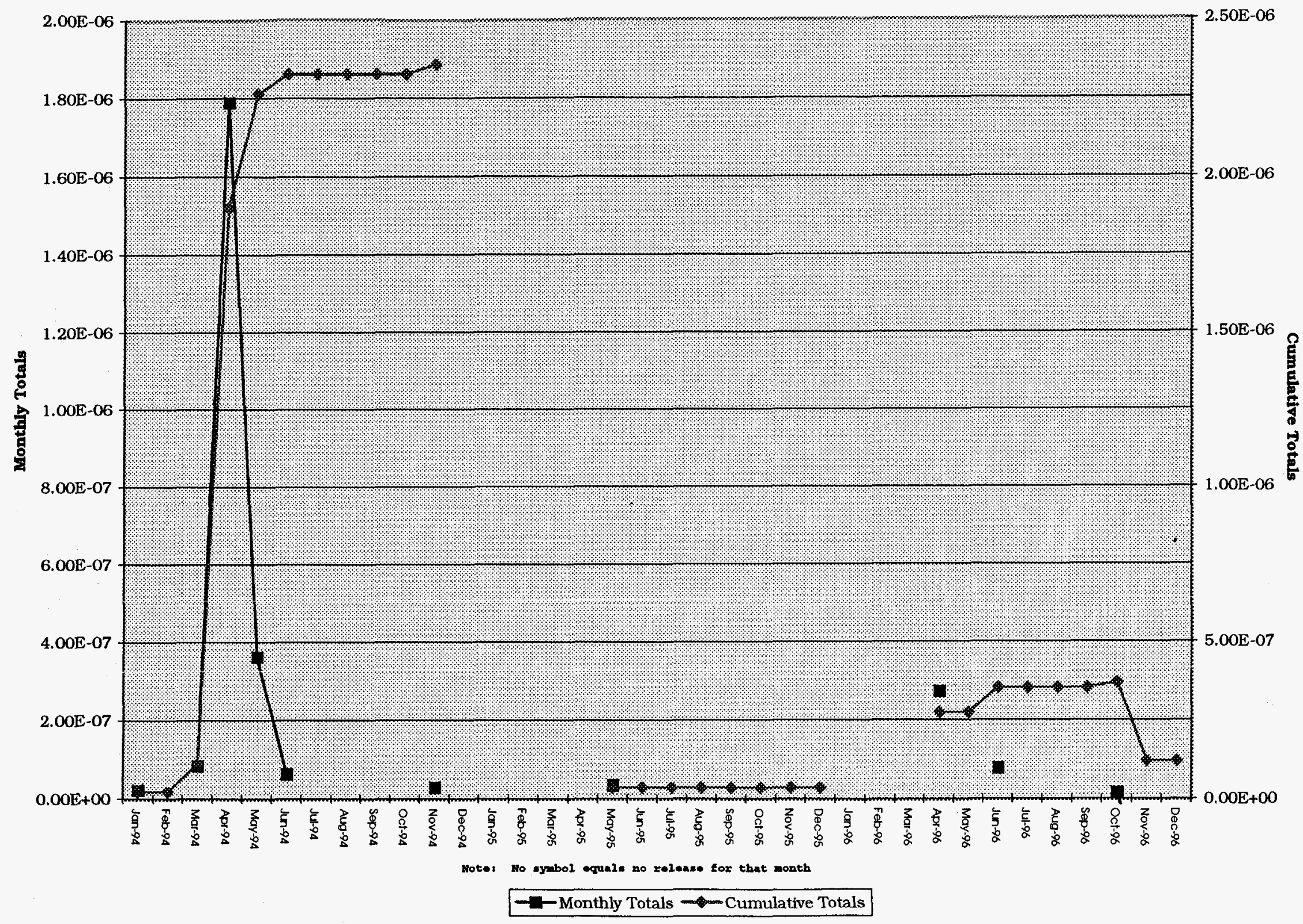


Table 2-4

AIRBORNE RELEASES FROM ICPP RAL STACK CY-1996

(curies)

\begin{tabular}{|c|c|c|c|c|c|c|c|c|c|c|c|c|c|}
\hline $\begin{array}{l}\text { RADIONUCLIDES } \\
\text { Co-60 }\end{array}$ & JAN & FEB & MAR & APR & MAY & JUN & JUL & AUG & SEP & OCT & Nov & DEC & $\begin{array}{l}\text { TOTAL } \\
0.00 E+00\end{array}$ \\
\hline Cs-134 & 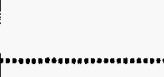 & 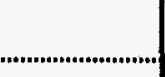 & & & & & & & & & & & $0.00 \mathrm{E}+00$ \\
\hline Cs-137 & 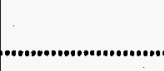 & & & & & & & & & & & & $0.00 E+00$ \\
\hline Pu-238 & 2.07E-09 & $1.45 \mathrm{E}-09$ & $9.81 \mathrm{E}-10$ & $7.52 \mathrm{E}-10$ & $2.83 E-09$ & $8.75 \mathrm{E}-10$ & $3.50 \mathrm{E}-08$ & $5.20 \mathrm{E}-10$ & 4.12E-09 & $5.56 \mathrm{E}-09$ & 3.11E-09 & 3.61E-09 & $6.09 \mathrm{E}-08$ \\
\hline 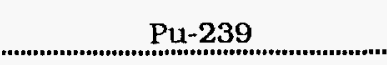 & $1.23 \mathrm{E}-10$ & 1.02E-09 & $1.24 \mathrm{E}-09$ & $9.27 \mathrm{E}-11$ & $1.39 \mathrm{E}-09$ & & $2.83 \mathrm{E}-09$ & 1.44E-09 & 3.25E-09 & $2.29 \mathrm{E}-09$ & $2.70 \mathrm{E}-09$ & 4.32E-09. & 2.07E-08 \\
\hline Ru-106 & (....... & 1....... & . & & & & & & & & & & $0.00 E+00$ \\
\hline $\mathrm{Sb}-125$ & & & & & & & & & & & & & $0.00 \mathrm{E}+00$ \\
\hline $\mathrm{Sr}-90$ & 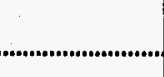 & 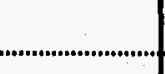 & 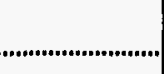 & & & & & & & & & & $0.00 \mathrm{E}+00$ \\
\hline TOTAL ACTIVITY & 2.19E-09 & $2.47 \mathrm{E}-09$ & $2.22 \mathrm{E}-09$ & $8.45 E-10$ & $4.22 \mathrm{E}-09$ & $8.75 \mathrm{E}-10$ & $3.78 \mathrm{E}-08$ & $1.96 \mathrm{E}-09$ & 7.37E-09 & 7.85E-09. & 5.81E-09 & 7.93E-09 & 8. $16 \mathrm{E}-08$ \\
\hline $\begin{array}{l}\text { TOTAL VOLUME } \\
\text { (cubic meters) }\end{array}$ & $2.08 \mathrm{E}+07$ & $1.95 \mathrm{E}+07$ & $2.08 \mathrm{E}+07$ & $2.02 \mathrm{E}+07$ & $2.08 \mathrm{E}+07$ & $2.02 \mathrm{E}+07$ & $2.08 \mathrm{E}+07$ & $2.08 \mathrm{E}+07$ & $2.02 \mathrm{E}+07$ & $2.08 \mathrm{E}+07$ & $2.02 \mathrm{E}+07$ & $2.08 \mathrm{E}+07$ & \\
\hline CUMULATIVE ACTIVITY & $2.19 \mathrm{E}-09$ & $4.66 \mathrm{E}-09$ & $6.88 \mathrm{E}-09$ & 7.73E-09 & $1.19 \mathrm{E}-08$ & $1.28 \mathrm{E}-08$ & $5.07 \mathrm{E}-08$ & $5.26 \mathrm{E}-08$ & $6.00 \mathrm{E}-08$ & $6.78 \mathrm{E}-08$ & $7.36 \mathrm{E}-08$ & $8.16 \mathrm{E}-08$ & \\
\hline
\end{tabular}

Illter. are pulled monthly

Blanke for sx-90 and pu ropxosont bolow dotoction and ramaining blankw roproxont not dotected in the gamma wean 


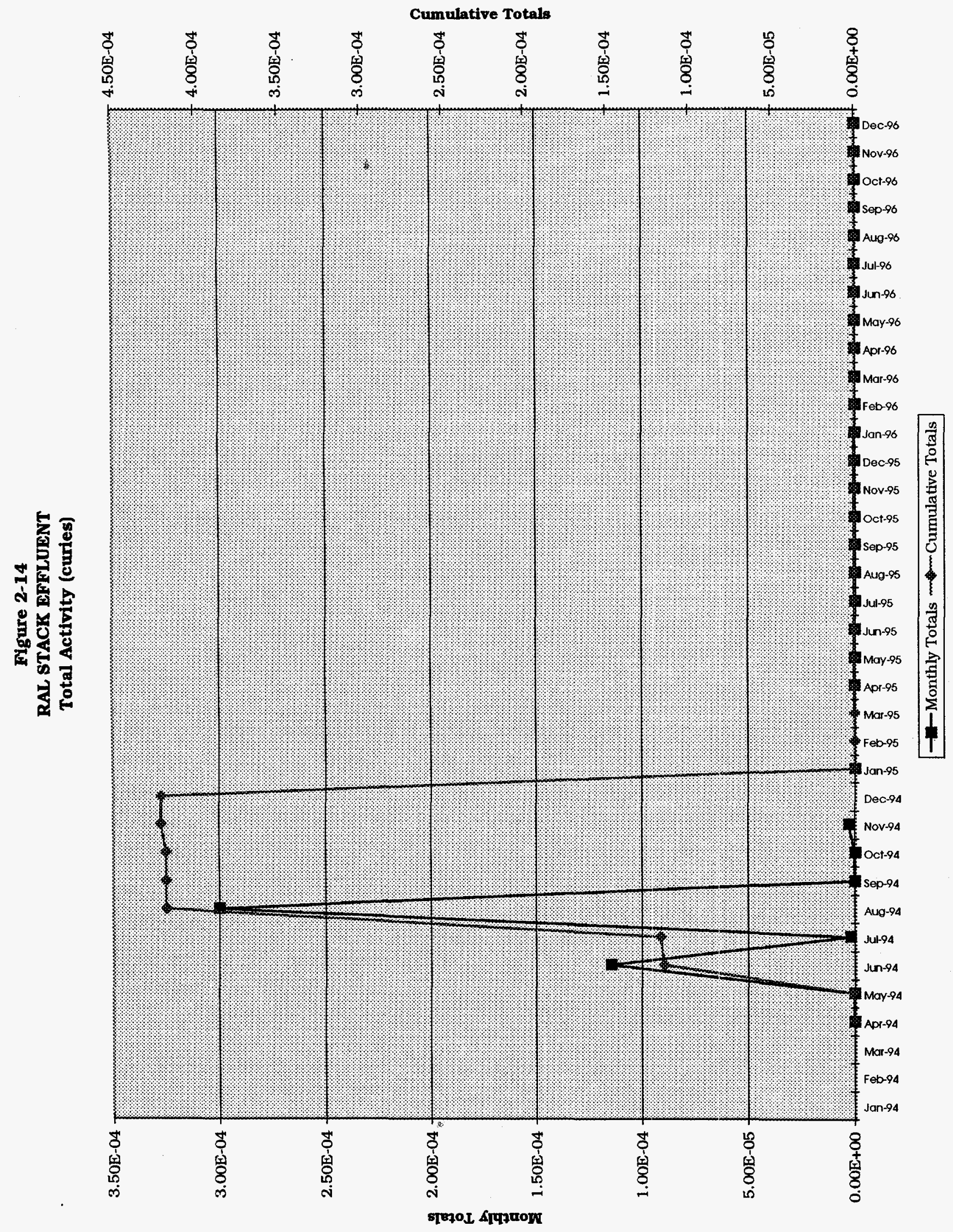


COAL FIRED STEAM GENERATOR FACILITY

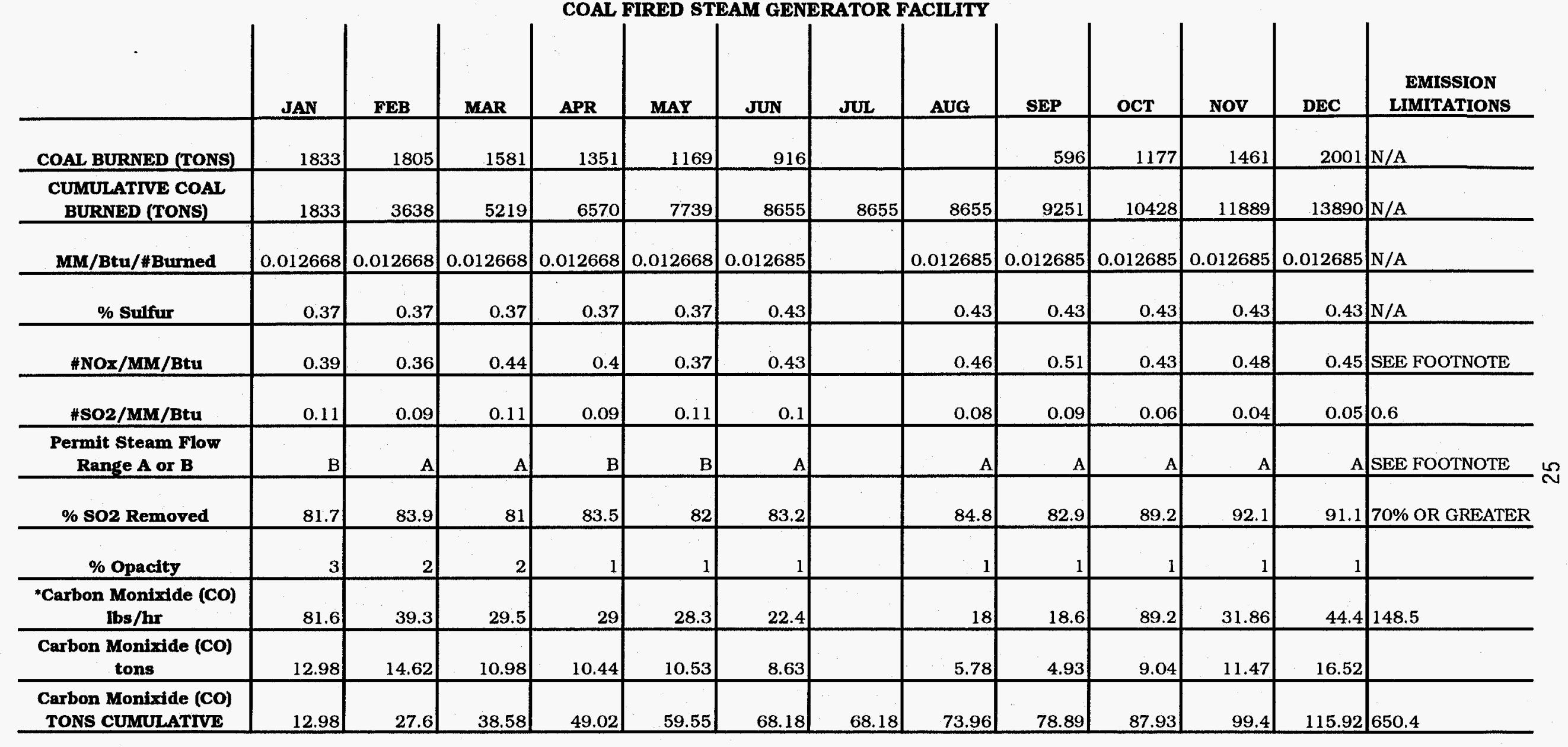

Opacity $=<20 \%$

Coal Burned (tons) $=\mathrm{N} / \mathrm{A}$

$\mathrm{mm}$ BTU/burned $=\mathbf{N A}$

$\%$ Sulfur $=\mathbf{N} / \mathbf{A}$

Nitrogen oxide (lbs. NOx/mmBTU) emissions shall not exceed an average of 0.5 pounds per million BTU's (Range B) averaged over a 24-hour period for steam flow greater or equal to 35000 lbs/hr.

Nitrogen oxide (lbs. NOx/mmBTU) emissions shall not exceed an average of 0.7 pounds per million BTU's (Range A) averaged over a 24-hour period for steam flow less than 35000 lbs/hr.

Sulfur dioxide (lbs. SO2/mmBTU) emissions shall not exceed an average of 0.6 pounds per million BTU of fuel input, averaged over a 24 hour period.

$\% \mathrm{SO} 2$ removal $=70 \%$ or greater and shall be calculated as an average over a 30 day period.

Steam flow $=$ N/A (Range B = steam load equal to or greater than 35000 pounds per hour and Range $A=$ steam load less than 35000 pounds per hour)

Carbon monoxide $(\mathrm{CO})$ emissions for the boilers shall not exceed an average of $148.5 \mathrm{lbs} / \mathrm{hr}$ averaged over a 30 day period.

REGULATORY WINCO DRIVERS: DOE 5400.1, PSD PERMIT PSD-XB 1-11 (2/86) AND REVISION TO PSD PERMIT PSD-XB1-11 (2/94) 


\section{LIQUID MONITORING}

\section{INTRODUCTION}

Liquid monitoring discussed in this report includes Service Waste system, and Sewage Treatment Plant. Quality Assurance objectives for measurement data and laboratory performance are listed in both the Quality Assurance Project Plan for the Analysis of Envirormental Samples by the LITCO Analytical Chemistry Section and the Special Technologies Quality Assurance Project Plans for Work subject to EPA QAMS-005/80.

\section{LIQUID RELEASES TO THE ENVIRONMENT}

\subsection{Service Waste System}

Liquid waste streams are generated from all areas of the ICPP. The waste streams vary in volume. Waste streams are disposed of through the Service Waste System. The Liquid Effluent Treatment and Disposal (LET\&D) Facility began operation on January 1, 1993.

Wastewater Land Application Permit (WLAP) LA-000130 for the Idaho Chemical Processing Plant (ICPP) percolation ponds was effective September 20, 1995. The permit authorizes construction, installation, modification or operation of a WLAP treatment system in conformance with requirements, limitations and conditions recuired in the permit.

Isotopic radionuclide and inorganic chemical release data for the Service Waste System for each month and year totals are presented in Table 3-1 and 3-2. Table 3-3 lists the monthly DCG release ratios respectively for individual radionuclides. DCGs are not release limits, but rather are screening values for considering Best Available Technology (BAT) for discharges and dose estimates.

The radionuclides reported are those that have been found in the past. Listed radionuclicles that do not have values shown were not observed during the reporting month or were below detection limits. Figure 3-1 depicts the total monthly activity released to the active Percolation Pond at ICPP.

Figure 3-2 depicts plutonium and figures 3-3 through 3-5 depicts uranium234, uranium-235, and uranium-238 found in the service waste stream.

Figures $3-6$ present trend information for $5 r-90$ in the Service Waste.

The ratio is calculated by dividing the detected radionuclide concentration by the established limit. Governmental regulations state that a corrected total ratio of 1.0 equal.s allowable radionuclide concentrations. The ICPP did not approach the total allowable release at any time during 1996. The ICPP did not exceed a ratio of 1.0 during any month in 1996. 
Table 3-1

LIGUID RELEASES FROM ICPP SERVICE WASTE CY-1996

(curies)

\begin{tabular}{|c|c|c|c|c|c|c|c|c|c|c|c|c|c|}
\hline $\begin{array}{l}\text { RADIONUCLIDES } \\
\text { Cs-134 }\end{array}$ & JAN & FEB & MAR & APR & MAY & JUN & JUL & AUG & SEP & oct & nov & DEC & TOTAL \\
\hline Cs-137. & & & $5.83 \mathrm{E}-04$ & & & & & & & & & & $5.83 E-04$ \\
\hline Eu-152 & & & & & & & & & & & & & \\
\hline Pu-238 & $2.96 \mathrm{E}-06$ & & & & & & & & & & & & $2.96 \mathrm{E}-06$ \\
\hline Pu-239. & & & & & & & & & & & & & \\
\hline Pu-241 & & & & & & & & & & & & & \\
\hline Ru-106 & & & & & & & & & & & & & \\
\hline sb-125 & & & & & & & & & & & & & \\
\hline Sr-90 & .1.69E-04 & & & & & & & & & & & & - \\
\hline $\mathrm{u}-234$ & 3.60E-04 & & & & & & & & & & & & $3360 \mathrm{E}-04$ \\
\hline $\mathrm{U}-235$ & ....:.06E-05 & & & & & & & & & & & & $1.06 \mathrm{E}-05$ \\
\hline U-238 & . $1.69 \mathrm{E}-04$ & & & & & & & & & & & & $1.69 \mathrm{E}-04$ \\
\hline TOTAL ACTIVITY & $7.12 \mathrm{E}-04$ & & . $5.83 \mathrm{E}-04$ & & & & & & & & & & 1.29E-03 \\
\hline $\begin{array}{l}\text { TOTAL VOLUME } \\
\text { (liters) }\end{array}$ & $2.12 \mathrm{E}+08$ & $1.75 \mathrm{E}+08$ & $1.61 \mathrm{E}+08$ & $2.02 \mathrm{E}+08$ & $1.51 \mathrm{E}+08$ & $1.76 \mathbb{E}+08$ & $1.88 \mathrm{E}+08$ & $1.86 \mathrm{E}+08$ & $1.72 \mathrm{E}+07$ & $2.05 \mathrm{E}+08$ & $1.90 \mathrm{E}+08$ & $2.01 \mathrm{E}+08$ & \\
\hline CUMULATIVE ACTIVITY & $7.12 \mathrm{E}-04$ & $7.12 \mathrm{E}-04$ & $1.29 \mathrm{E}-03$ & $1.29 \mathrm{E}-03$ & $1.29 \mathrm{E}-03$ & $1.29 \mathrm{E}-03$ & $1.29 \mathrm{E}-03$ & $1.29 \mathrm{E}-03$ & $1.29 \mathrm{E}-03$ & $1.29 \mathrm{E}-03$ & $1.29 \mathrm{E}-03$ & $1.29 \mathrm{E}-03$ & \\
\hline
\end{tabular}


Table 3-2

ICPP SERVICE WASTE CY-1996

(mg/L)

\begin{tabular}{|c|c|c|c|c|c|c|c|c|c|c|c|c|}
\hline SUBSTANCE & JAN. & FEB. & MAR. & APR. & MAY & JUN. & JuL. & AUG. & SEP. & oct. & Nov. & DEC. \\
\hline Aluminum (Al) & & & $3.72 \mathrm{E}-02$ & & & & & & & & & \\
\hline \multicolumn{13}{|l|}{ Arsenic (As) } \\
\hline Barium (Ba) & $1.09 \mathrm{E}-01$ & $8.10 \mathrm{E}-02$ & $9.49 \mathrm{E}-02$ & $7.90 \mathrm{E}-02$ & $6.15 \mathrm{E}-02$ & $1.07 \mathrm{E}-01$ & $1.33 \mathrm{E}-01$ & $1.00 \mathrm{E}-01$ & $7.35 \mathrm{E}-02$ & $6.32 \mathrm{E}-02$ & $9.61 \mathrm{E}-02$ & $8.00 \mathrm{E}-02$ \\
\hline Cadmium (Cd) & & & & & & & 4.30E- 03 & & & & & \\
\hline Chloride Ion & $3.49 \mathrm{E}+02$ & $2.94 \mathrm{E}+02$ & $2.65 \mathrm{E}+02$ & $3.42 \mathrm{E}+02$ & $2.10 \mathrm{E}+02$ & $2.86 \mathrm{E}+02$ & $3.29 \mathrm{E}+02$ & $2.77 \mathrm{E}+\mathrm{O} 2$ & $2.06 \mathrm{E}+02$ & $2.47 \mathrm{E}+02$ & $2.80 \mathrm{E}+02$ & $2.56 \mathrm{E}+02$ \\
\hline Chromium (Cr) & $5.20 \mathrm{E}-03$ & $7.70 \mathrm{E}-03$ & $5.40 \mathrm{E}-03$ & & $4.10 \mathrm{E}-03$ & & & $5.20 \mathrm{E}-03$ & & $3.40 \mathrm{E}-03$ & & $5.40 \mathrm{E}-03$ \\
\hline Copper (Cu) & $5.80 \mathrm{E}-\mathrm{O} 3$ & $9.80 \mathrm{E}-03$ & & & & & & & & & & \\
\hline Fluoride Ion & & & & $2.10 \mathrm{E}-01$ & & $2.41 \mathrm{E}-01$ & $2.40 \mathrm{E}-01$ & $2.48 \mathrm{E}-01$ & $2.40 \mathrm{E}-01$ & $2.90 \mathrm{E}-01$ & $2.40 \mathrm{E}-01$ & $2.70 \mathrm{E}-01$ \\
\hline Iron (Fe) & $5.63 \mathrm{E}-02$ & $2.01 \mathrm{E}-02$ & $1.90 \mathrm{E}-02$ & $2.08 \mathrm{E}-02$ & $1.66 \mathrm{E}-02$ & $1.87 \mathrm{E}-02$ & $1.00 \mathrm{E}-02$ & 8.00E-03 & $2.89 \mathrm{E}-02$ & $8.60 \mathrm{E}-03$ & $1.62 \mathrm{E}-02$ & 2.22E-02 \\
\hline Lead $(\mathrm{Pb})$ & & & & & & $2.19 \mathrm{E}-02$ & & & 0.0311 & & & \\
\hline Manganese (Mn) & $3.20 \mathrm{E}-03$ & $3.50 \mathrm{E}-03$ & $2.60 \mathrm{E}-03$ & & & $1.80 \mathrm{E}-03$ & 8.00E-04 & $9.00 \mathrm{E}-04$ & $1.30 \mathrm{E}-03$ & $1.80 \mathrm{E}-03$ & $2.00 \mathrm{E}-03$ & $1.60 \mathrm{E}-03$ \\
\hline \multicolumn{13}{|l|}{ Mercury $(\mathrm{Hg})$} \\
\hline Nitrate (NO3-N) & $4.21 \mathrm{E}+00$ & $5.70 \mathrm{E}+00$ & $4.60 \mathrm{E}+00$ & $5.40 \mathrm{E}+00$ & $5.10 \mathrm{E}+00$ & $5.10 \mathrm{E}+\mathrm{OO}$ & $4.43 \mathrm{E}+00$ & $5.28 \mathrm{E}+00$ & $4.30 \mathrm{E}+00$ & & $4.90 \mathrm{E}+00$ & $5.30 \mathrm{E}+00$ \\
\hline Nitrite Ion (NO2) & & & & & & & & & & & $3.30 \mathrm{E}-01$ & $3.30 \mathrm{E}-01$ \\
\hline Phosphate Ion & 4.10E-01 & & & & $3.60 \mathrm{E}-01$ & & & & & & $2.60 \mathrm{E}-01$ & \\
\hline Selentum (Se) & $3.01 \mathrm{E}-03$ & & $4.20 \mathrm{E}-03$ & & & & & & & & & \\
\hline \multicolumn{13}{|l|}{ Silver (Ag) } \\
\hline Sodium (Na) & $1.92 \mathrm{E}+02$ & $1.66 \mathrm{E}+02$ & $1.78 \mathrm{E}+02$ & $1.67 \mathrm{E}+02$ & $1.36 \mathrm{E}+02$ & $1.77 \mathrm{E}+02$ & $1.70 \mathrm{E}+02$ & $1.77 \mathrm{E}+02$ & $1.45 \mathrm{E}+02$ & $1.51 \mathrm{E}+02$ & $1.57 \mathrm{E}+02$ & $1.39 \mathrm{E}+02$ \\
\hline Sulfate Ion & $2.80 \mathrm{E}+01$ & $3.41 \mathrm{E}+01$ & $2.76 \mathrm{E}+01$ & $2.81 \mathrm{E}+01$ & $2.78 \mathrm{E}+01$ & $2.80 \mathrm{E}+01$ & $2.65 \mathrm{E}+01$ & $2.68 \mathrm{E}+01$ & $2.68 \mathrm{E}+01$ & $2.68 \mathrm{E}+01$ & $2.82 \mathrm{E}+01$ & $2.78 \mathrm{E}+01$ \\
\hline Total Disolved Solids (TDS) & $6.98 \mathrm{E}+02$ & $5.66 \mathrm{E}+02$ & $6.55 \mathrm{E}+02$ & $6.32 \mathrm{E}+02$ & $5.49 \mathrm{E}+02$ & $6.86 \mathrm{E}+02$ & $7.04 \mathrm{E}+02$ & $6.70 \mathrm{E}+02$ & $5.60 \mathrm{E}+02$ & $4.73 \mathrm{E}+02$ & $6.64 \mathrm{E}+02$ & $6.29 \mathrm{E}+02$ \\
\hline Conductivity (uMhos) & 1,500 & 1,036 & 1250 & 1,150 & 1,030 & 1,350 & 1,400 & 1,275 & 1070 & 1,160 & 1,280 & 1,190 \\
\hline $\mathrm{pH}$ & 8.46 & 8.5 & 8.42 & 8.5 & 8.27 & 8.56 & 8.66 & 8.55 & 8.39 & 8.45 & 8.59 & 8.64 \\
\hline TKN & & & & & & & & 0.276 & & & & 0.225 \\
\hline
\end{tabular}

Blanks equal below detection limits or not detected 


\begin{tabular}{|c|c|c|c|c|c|c|c|c|c|c|c|c|c|}
\hline RADIONUCLIDES & JAN & FEB & MAR & APR & MAY & JUN & $\mathrm{JUL}$ & AUG & SEP & $\mathrm{OCT}$ & NOV & $\mathrm{DEC}$ & DCG \\
\hline Cs-134 & & & & & & & & & & & & & $2.00 E-06$ \\
\hline Cs-137 & & & $1.21 \mathrm{E}-03$ & & & & & & & & & & $3.00 \mathrm{E}-06$ \\
\hline Eu-152 & & & & & & & & & & & & & $1.00 \mathrm{E}-05$ \\
\hline Pu-238 & $3.50 \mathrm{E}-04$ & & & & & & & & & & & & 4.00E-08 \\
\hline Pu-239 & & & & & & & & & & & & & $3.00 \mathrm{E}-08$ \\
\hline Pu-241 & & & & & & & & & & & & & 2.00E-06 \\
\hline Ru-106 & & & & & & & & & & & & & $6.00 \mathrm{E}-06$ \\
\hline $\mathrm{Sb}-125$ & & & & & & & & & & & & & $.5 .00 \mathrm{E}-05$ \\
\hline Sr-90 & $7.97 \mathrm{E}-04$ & & & & & & & & & & & & 1.00E-06 \\
\hline $\mathrm{U}-234$ & $3.40 \mathrm{E}-03$ & & & & & & & & & & & & 5.00E-07 \\
\hline $\mathrm{U}-235$ & $8.33 \mathrm{E}-05$ & & & & & & & & & & & & $\begin{array}{l}6.00 \mathrm{E}-07 \\
.007\end{array}$ \\
\hline $\mathrm{U}-238$ & $1.33 \mathrm{E}-03$ & & & & & & & & & & & & $6.00 \mathrm{E}-07$ \\
\hline
\end{tabular}




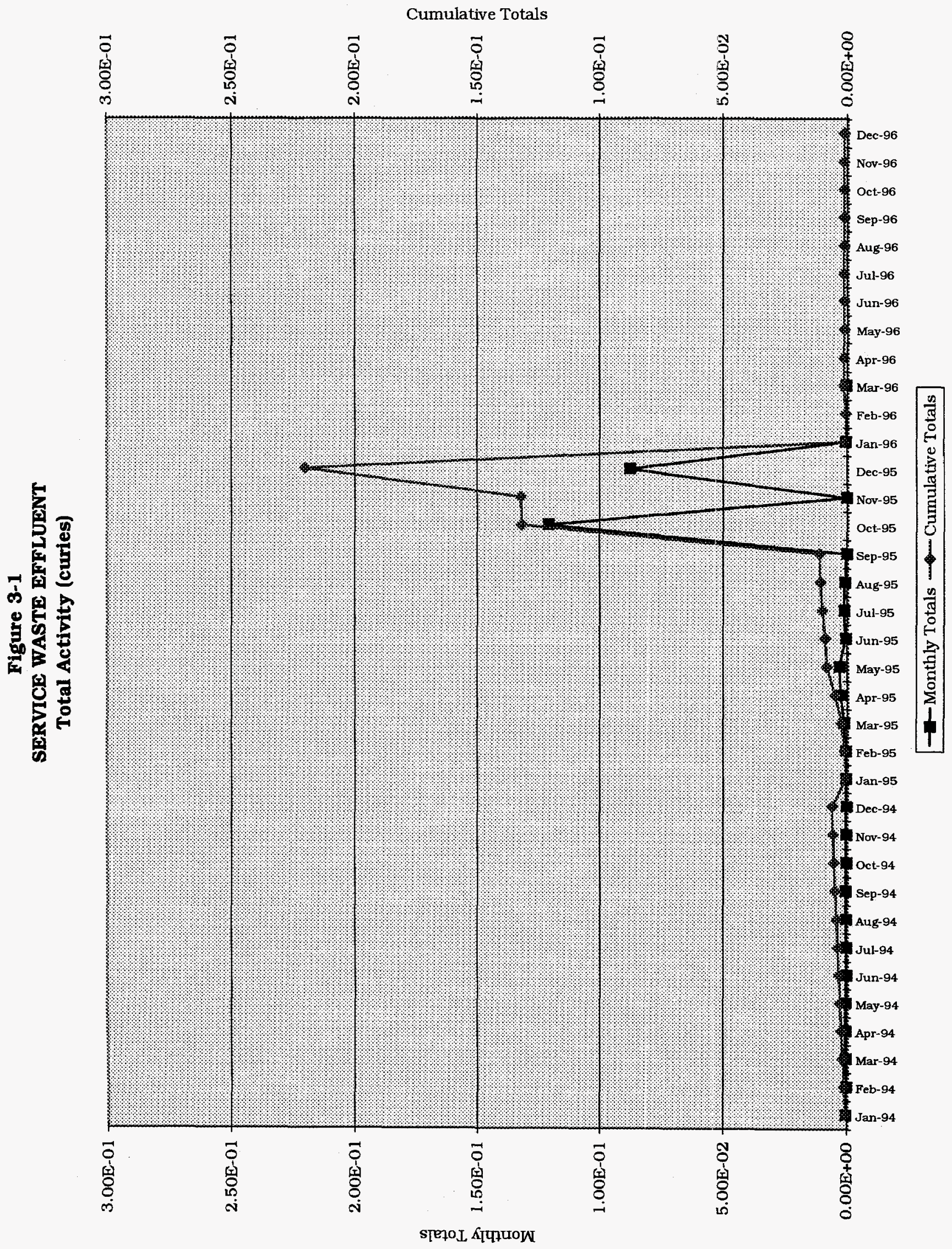




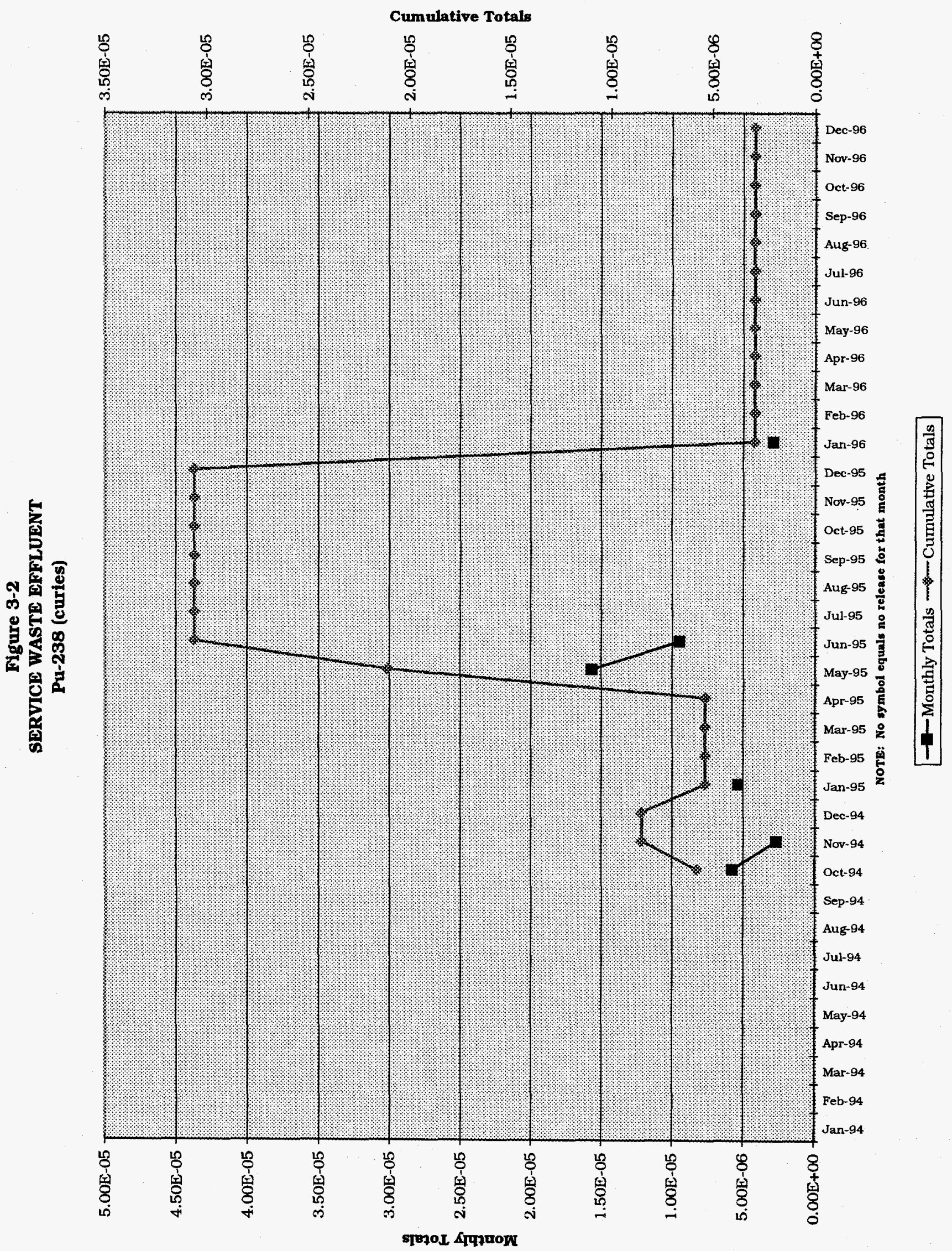




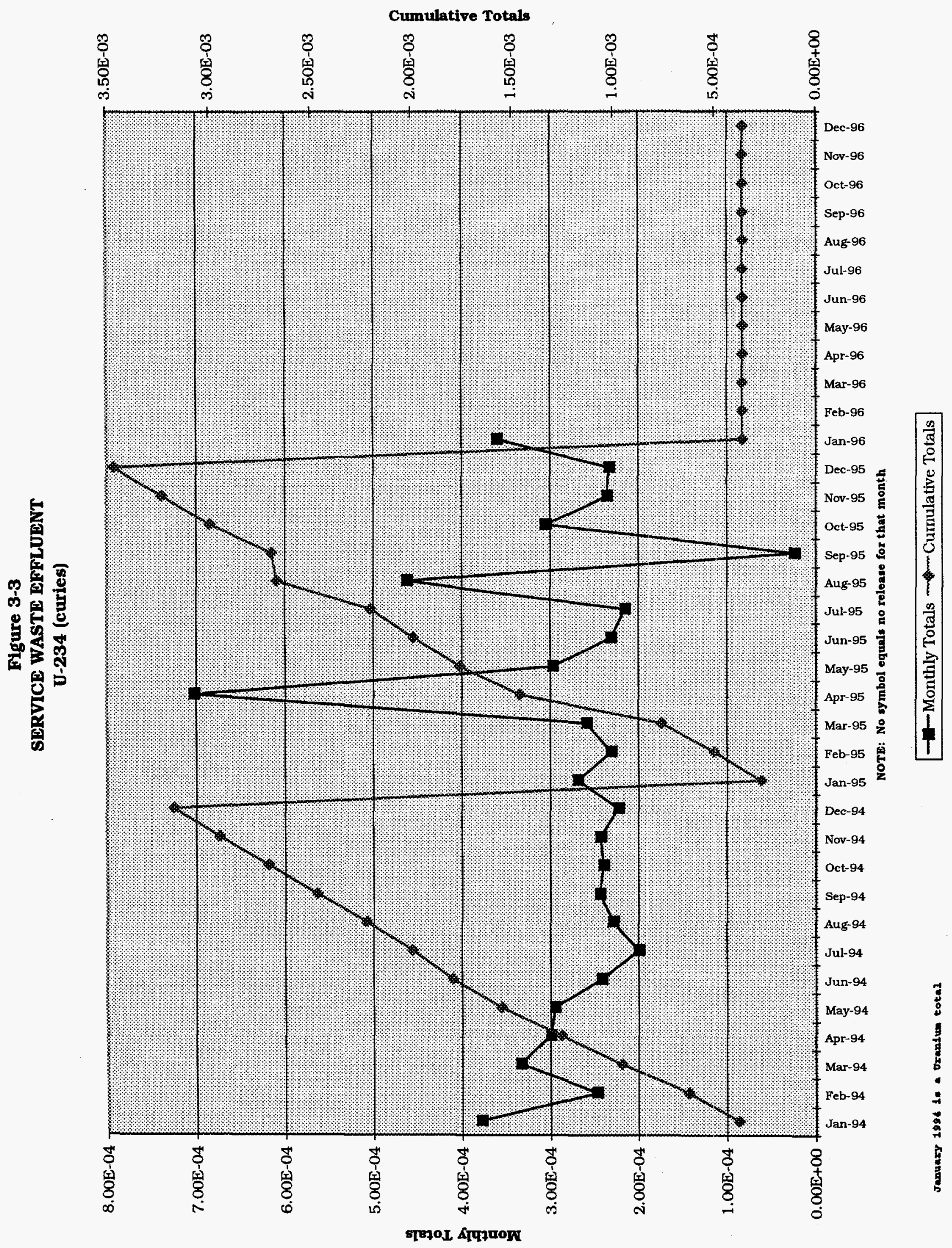



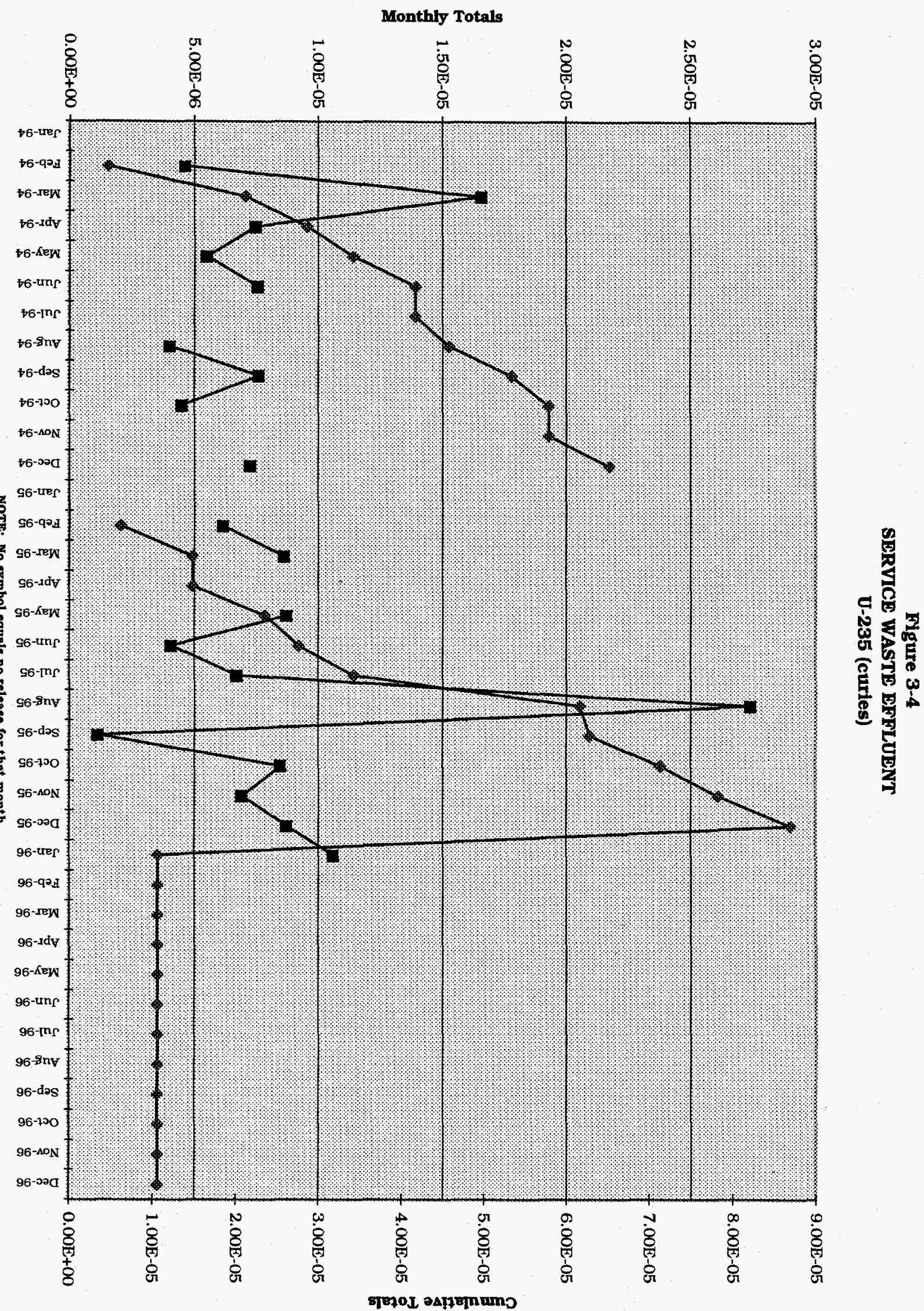
Figure 3-5

SERVICE WASTE EFFLUENT

U-238 (curies)

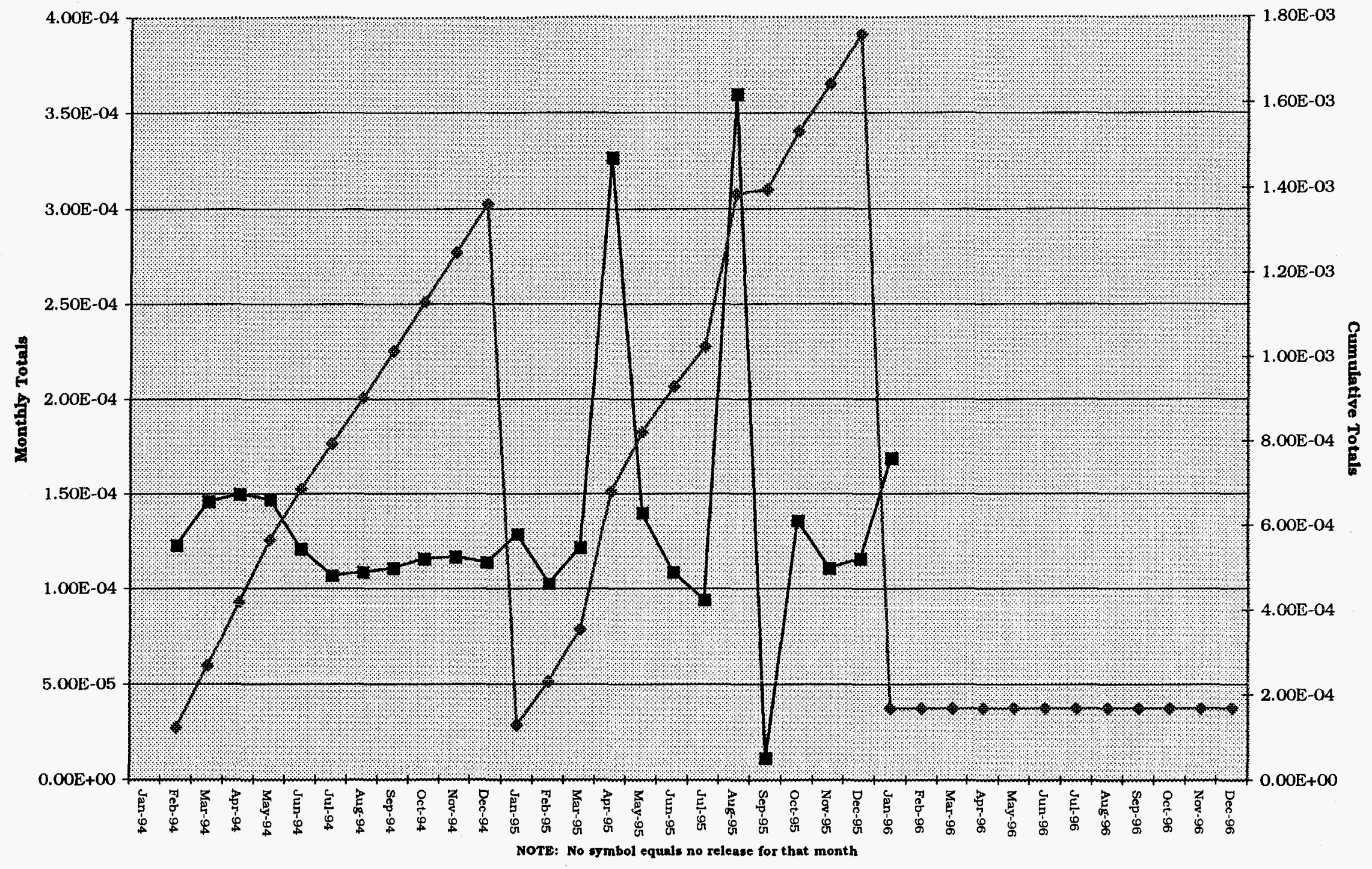

- -Monthly Totals $\rightarrow$ Cumulative Totals 


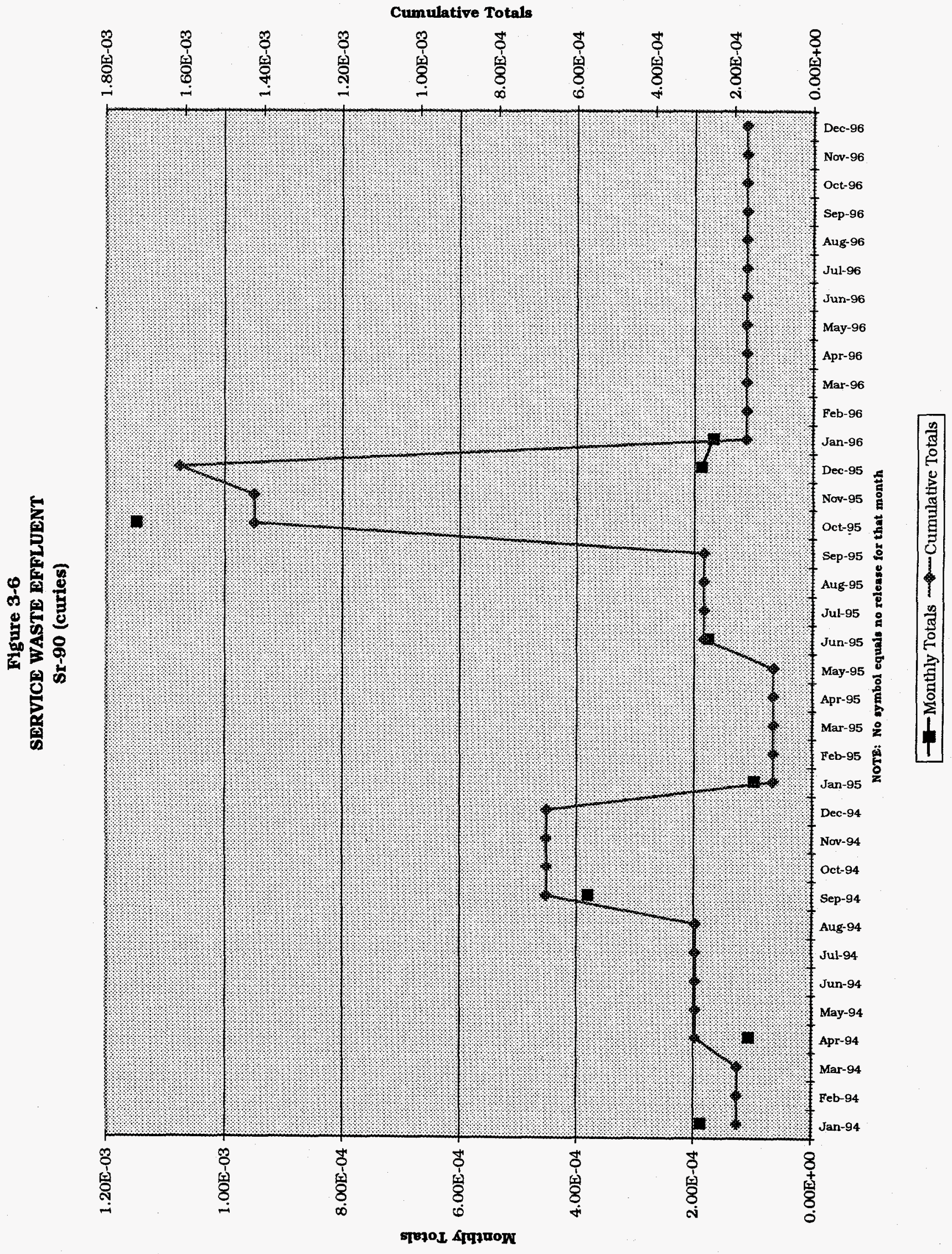




\subsection{Sewage Treatment Plant}

Domestic waste water at the ICPP is pumped to the Waste water Treatment Facility that is located outside the security fence. LITCO Power Plant Services is responsible for the operation and maintenance of the Waste Water Treatment Facility. Wastewater Land Application Permit (WLAP) LA000115-02 became effective september 17, 1995. The permit authorizes the wastewater facility to operate subject to specific requirements specified in the permit. LITCO Environmental takes monthly 24 hour composite samples for permit compliance and radionuclides. The radionuclides sample is analyzed for gross alpha, gross beta and gamma.

The IITCO Environmental Affairs Department monitors the operation and performance of the domestic Waste Water Treatment Plant. Table 3-4 1ists the monthly Biological Oxygen Demand (BOD), Dissolved Oxygen (DO) and $\mathrm{pH}$ for 1996 .

Monthly influent (raw) and effluent (final) Biological Oxygen Demand (BOD) concentrations are shown in Figure 3-7. The difference in concentrations between influent BOD and effluent BOD represents the treatment efficiency. Dissolved Oxygen (DO) levels in the influent and effluent are indicators of proper operation. Values for influent and effluent DO are shown in Figure 3-8. Figure 3-9 lists the $\mathrm{pH}$ and Figure 3-10 represents STP volume.

\subsection{ICPP Injection Well}

The ICPP injection well was permanently sealed in November 1989. 
Table 3-4

SEWAGE TREATMENT PLANT ANALYSIS

CY-1996

\begin{tabular}{|c|c|c|c|c|c|c|c|c|c|c|c|c|}
\hline INFLUENT BOD & $\begin{array}{l}\text { JAN } \\
149\end{array}$ & $\begin{array}{l}\text { FEB } \\
106\end{array}$ & $\begin{array}{l}\text { MAR } \\
73 \\
7 . . . .\end{array}$ & $\begin{array}{l}\text { APR } \\
146\end{array}$ & $\begin{array}{r}\text { MAY } \\
129 \\
129\end{array}$ & $\begin{array}{c}\text { JUN } \\
10 \\
1 . . . . . . .\end{array}$ & $\begin{array}{l}\text { JUL } \\
91 \\
9 . . . . .\end{array}$ & $\begin{array}{c}\text { AUG } \\
86 \\
. . .\end{array}$ & 97 & 39 & $\begin{array}{l}\text { Nov } \\
193 \\
\end{array}$ & $\begin{array}{l}\text { DEC } \\
64 \\
6 . . . . . . . .\end{array}$ \\
\hline EFFLUENT BOD & $\ldots$ & .22 &....... & ........ & .8. & $\ldots 1$ & 6 & 3. & $4 . . . . .$. & 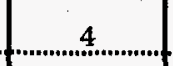 & $\ldots 1$ & 5 \\
\hline EFFICIENCY &. $.97 \%$ & $79 \%$ & $90 \%$ & $.95 \%$ & $94 \%$ & $90 \%$ & $93 \%$ & $97 \%$ & $96 \%$ & $90 \%$ & $.99 \%$ & $92 \%$ \\
\hline INELUENT DO & 0.84 & $.1 .27 \ldots$ & 0.59 & 0.68 & 0.5 & 0.61 & 0.36 & 0.71 & .0 .52 & 1.16 & 0.59 & 0.75 \\
\hline EEFLUENT DO & 8.08 & 6.89 & 7.89 & 4.92 & 6.14 & 3.23 & 4.97 &.. .23 & 6.12 & 6.72 & 10.12 & 8.99 \\
\hline INFLUENT PH & .8 .23 & 8.13 & 8.07 & 7.98 & 7.95 & 7.82 & 7.99 & 7.9 & 8.00 & .7 .92 & 8.22 & 8.2 \\
\hline EFFLUENT & 7.44 & 7.31 & 7.38 & 7.28 & 7.43 & 7.16 & 7.69 & 7.69 & 7.73 & .....44 & $7.77 \ldots$ & 7.62 \\
\hline INFLUENT VOLUME (L) & $8.67 \mathrm{E}+06$ & $6.96 \mathrm{E}+06$ & $4.88 \mathrm{E}+06$ & $4.92 E+06$ & $5.19 \mathrm{E}+06$ & $3.52 \mathrm{E}+06$ & $4.88 \mathrm{E}+06$ & $6.40 \mathrm{E}+06$ & $5.64 \mathrm{E}+06$ & $9.92 E+06$ & $7.12 \mathrm{E}+06$ & $6.78 \mathrm{E}+06$. \\
\hline EFFLUENT VOLUME (L) & $4.50 \mathrm{E}+06$ & $5.49 \mathrm{E}+06$ & $|4.31 \mathrm{E}+06|$ & $3.69 \mathrm{E}+06$ & $3.50 \mathrm{E}+06$ & $1.53 \mathrm{E}+06$ & $|1.99 \mathrm{E}+06|$ & $2.56 \mathrm{E}+06$ & $|2.13 E+06|$ & $|3.51 E+06|$ & $|3.26 \mathrm{E}+06|$ & $3.74 \mathrm{E}+06$ \\
\hline
\end{tabular}




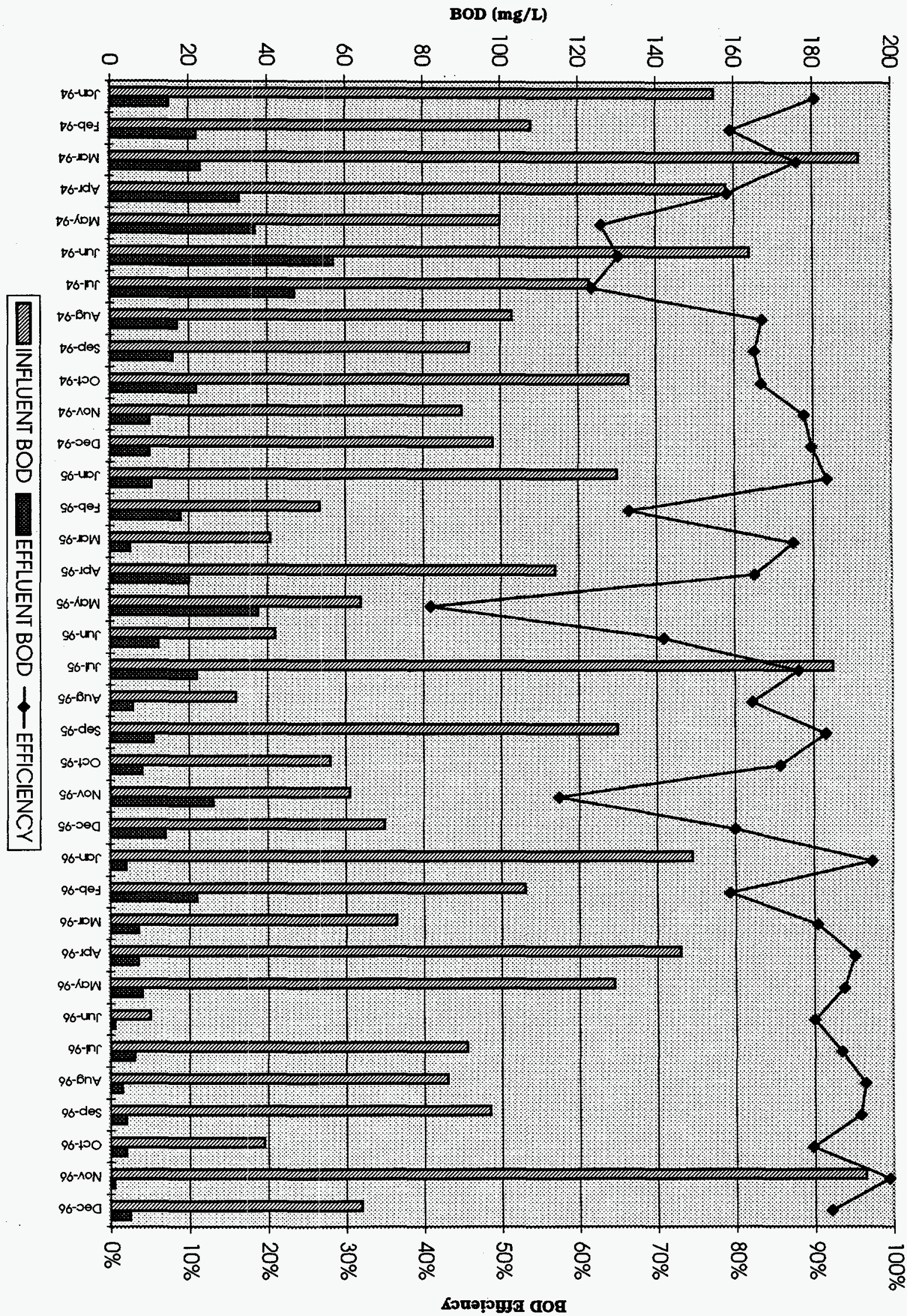

罢最 


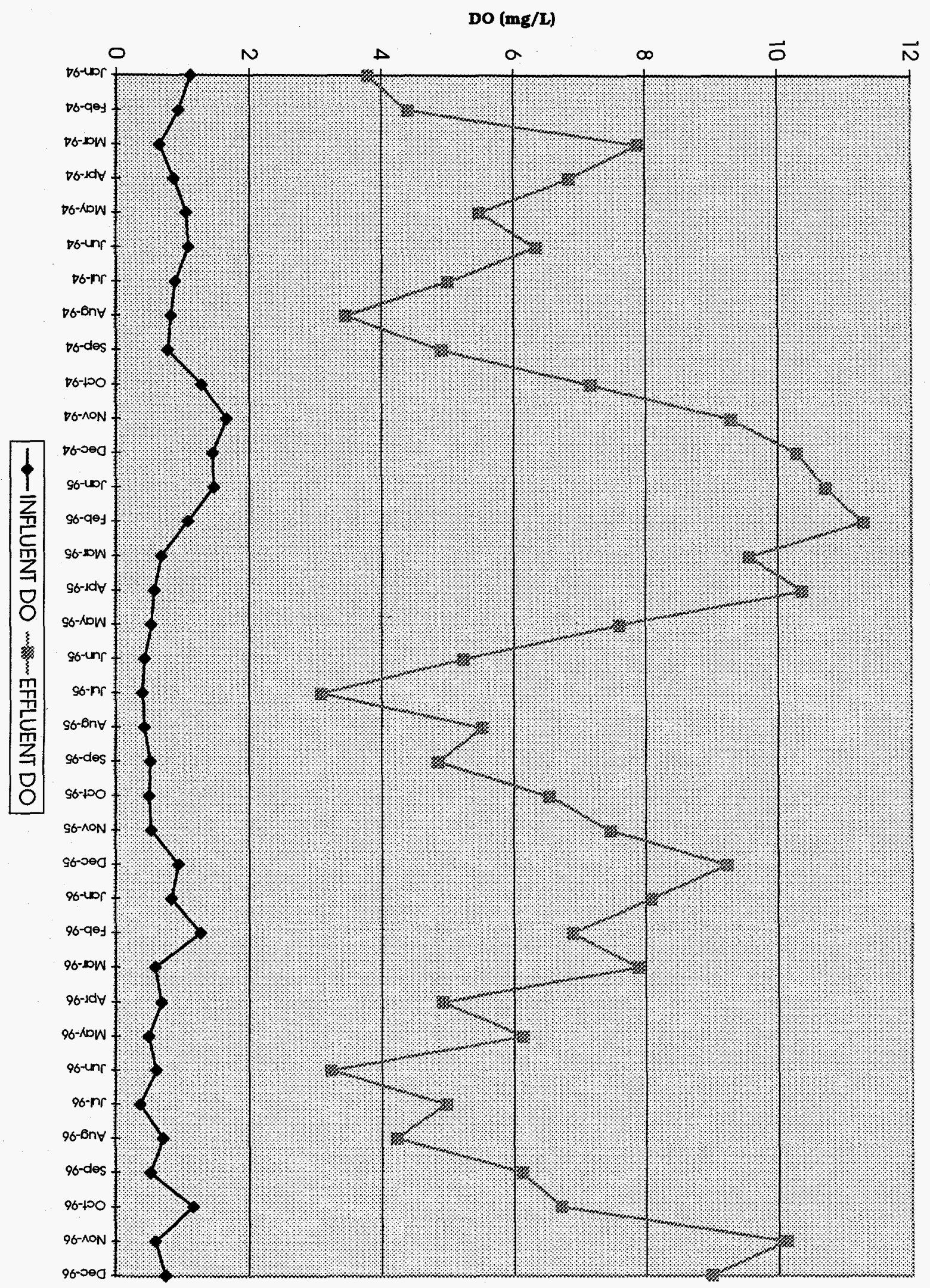

罢 


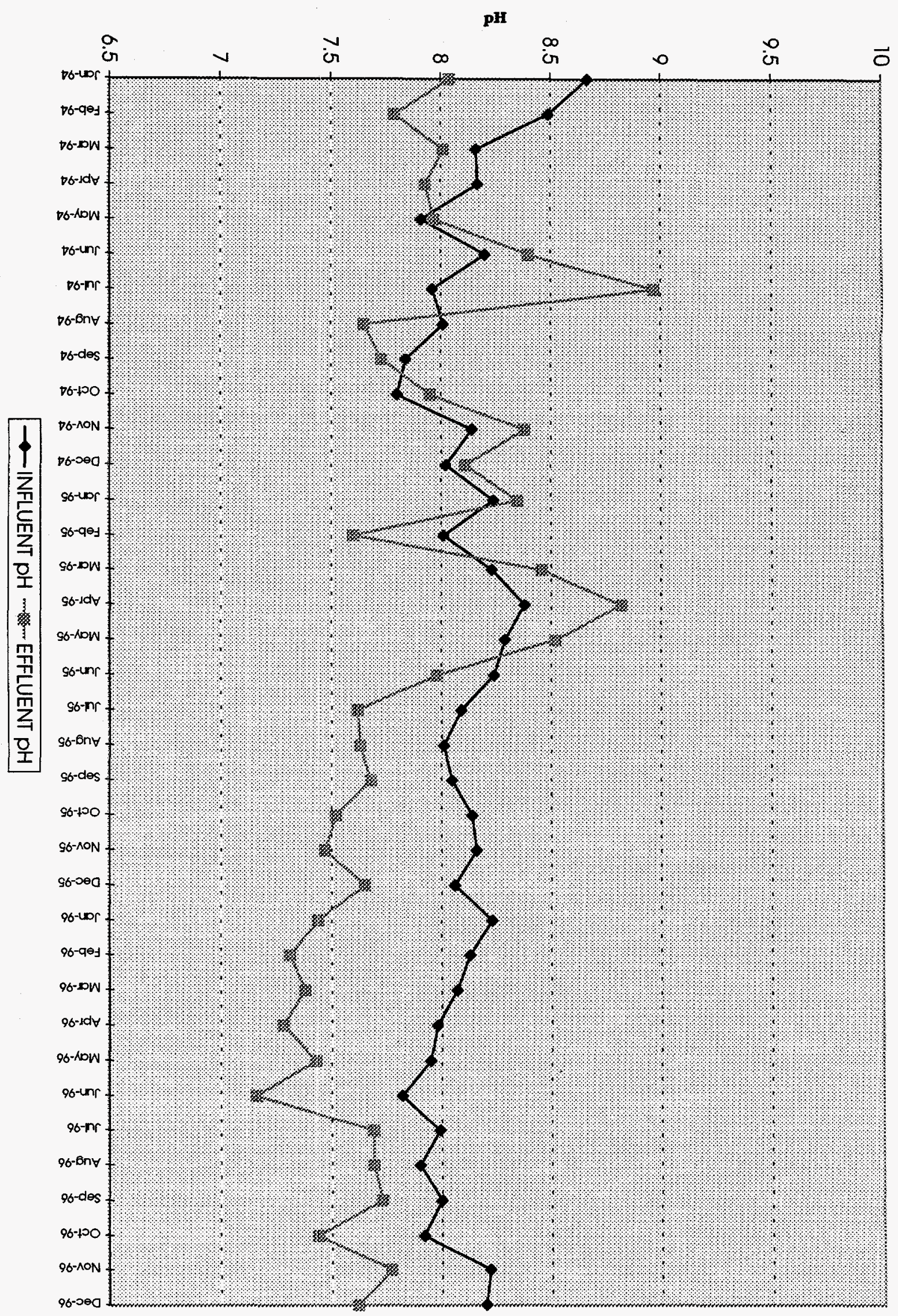

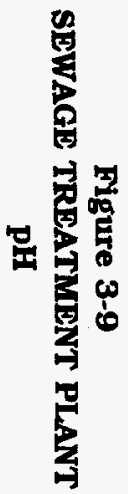


Liters

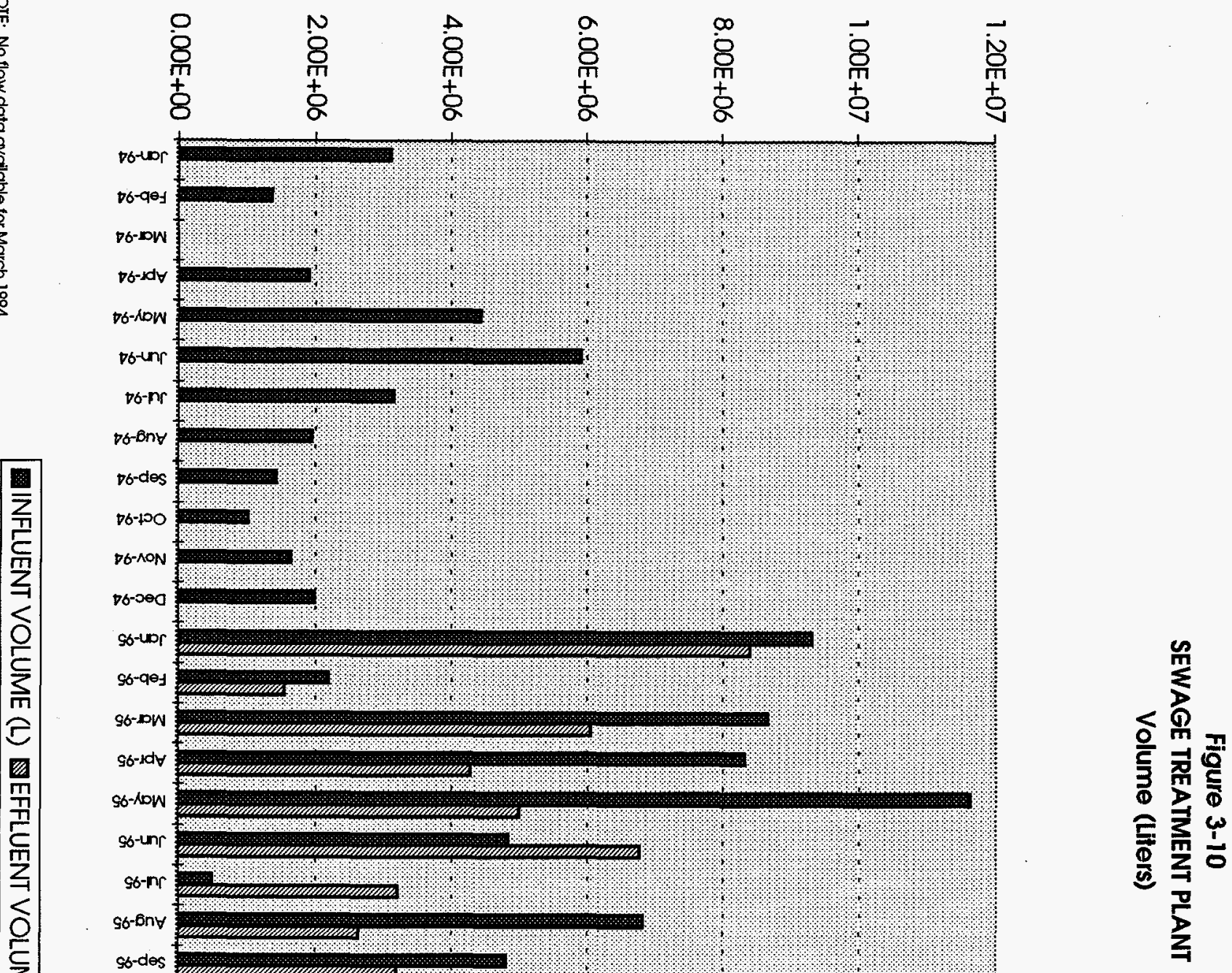

